American Journal of Law and Legal Studies
(ISSN:2638-2202)

\title{
Intellectual Property Rights in Nigeria: Issues and Challenges
}

\section{Nwanna, Clifford Ezekwe (Ph.D)}

Faculty of Environmental Sciences, Nnamdi Azikiwe University, Awka, Anambra State, Nigeria

\section{ABSTRACT}

This study is on issues and Challenges facing intellectual Proper-

*Correspondence to Author:

ty right in Nigeria. Although intellectual Property right laws exist in Nigeria, it is observable that the enforcement of this aspect of Nwanna, Clifford Ezekwe (Ph.D) law is not taken seriously compared to that of real property. This problem has caused a decrease in the economic value of the productive sector, especially the creative industry, in Nigeria, and a corresponding decrease in our Gross Domestic Product (GDP). In view of this problem, the study aims at investigating the issues and challenges affecting intellectual property right in Nigeria, with a view to enlightening the public on the availability and role of intellectual property laws in our Jurisdiction and to proffer solutions on how to achieve more effective enforcement. The study employs a qualitative research approach, while information was sourced primarily through oral source mainly interviews with learned Jurists and practitioners in the creative industry. Secondary sources of information used comprise written sources which include decided cases, Books, Journals, Newspapers and dissertations/project. The study revealed that if intellectual properties are properly protected and the applicable laws enforced, Nigeria will witness a phenomenal rise in the economic value of most productive sector in Nigeria and a corresponding increase in Gross Domestic Product. The study will recommend among others, to improve on legal education in Nigeria by generating best practices and approaches that can be employed to redesign legal education to make it responsive to contemporary realities and needs of the society.

Keywords: Intellectual Property, rights, issues, challenges, legal Education 


\section{Introduction}

It is a truism that original knowledge and creative expression of ideas form the bases of successful business in the $21^{\text {st }}$ century, in view of this, the protection of trade and business information in order to gain a competitive advantage or economic monopoly accrued from an original idea becomes indispensible. Intellectual property refers to property from original thought protected by law. They include; patent, trademark and copyright kur ${ }^{1}$ reasons that:

The right obtainable in intellectual property are conferred by states and or by common Law on an individual or a corporate body with respect to the product of his or her intellect, guaranteeing the exclusive control of his work for limited period. The object of protection here is usually a work of the mind or human intellect.

Enforcement of Intellectual Property right in Nigeria still suffers some draw backs, especially in the aspect of litigation. Another biting issue is that of piracy which takes place in Nigeria and sometimes with offenders operating outside the jurisdiction of the owner of the intellectual property. Against this back drop there is still need to modify the law governing intellectual property

\section{Statement of the Problem}

Laws that protect intellectual property in Nigeria has been existing since 1900 and has been undergoing modification till today. The present stage of intellectual Law protection in Nigeria enacted in 1988 as a replacement of the copyright Act of 1970. Agreed that the present Act of 1988 is actually an improvement of the former especially in solving the various lacunas in the erstwhile Act, there is still room for improvement to meet up with the dynamism of the $21^{\text {st }}$ century technological and socio-legal problems. In view of this, the study examines the problem of intellectual property protection, interrogates the gaps in the current intellectual property protection Laws and proffer solution to such identified problems.

\section{Research Questions}

1. What is the level of awareness of intellectual property Laws among Nigerian citizens?

2. If they are not aware, what are the causes of this lack of awareness?

3. Are there areas of weakness in the present Nigeria copyright Act or are there weaknesses in enforcement?

\section{Aim and Objectives of the Study}

The study aims at critically examining issues and challenges of intellectual property right in Nigeria and proffer solutions to identified problems. The research is also set to achieve the following objectives:

To enlighten the public on the availability and role of intellectual property Laws in our Jurisdiction.

. To examine and evaluate critically, the necessary statutory provisions in intellectual property matters.

i. To proffer solutions on how to achieve more effective enforcement.

\section{Scope and Limitation}

The study is intended towards investigating the intellectual property right awareness among Nigerians in the creative industry, from 1970 to 2016.

The major limitation which this research suffered is that there has been few personal suits against intellectual rights infringement in Nigeria, most of such cases were settled out of court. This made it difficult for the researcher to get information since there were few records of such cases since the court did not make any final decision on those cases.

\section{Significance of the Study}

This study will expose the readers, both Lawyers and non-Lawyers to an in-depth knowledge of intellectual property right in Nigeria. This is especially important because people look at this area of Law as rather specialized; this ought not to be so.

Awareness of intellectual property Laws will inform more people including Law students and laymen about the benefits from the commercial 
value attached to the rights involved. More so, the right to stop a commercial activity of another person has now been recognized in Law.

The awareness created by this research will also help to check the ever rising trend in piracy, particularly in the Nigerian creative industry.

\section{Research Method}

The study employs a qualitative research method. Sources of data used are from both primary and secondary sources. The primary sources comprise mainly oral sources which include interviewing prominent Jurists, students and people, mostly from the creative industry. Here interview guide and questionnaires were used. The secondary sources are written materials and they include; Law reports, decided cases, Law Journals, magazines, Newspaper and Internet.

Information obtained from oral sources and decided cases superseded information from books and internet because the oral information are first witness account, while some detailed might be lost by the second witness while putting down his/her report. The books and magazines played a secondary and complimentary role.

\section{Literature Review}

\section{Conceptual Framework}

The concept of intellectual property are that of intangible property which have no physical existence. They are "chooses in action" and corporeal hereditaments. The term has no acceptable definition. The Oxford Dictionary of Law $^{2}$ defined intellectual property as "intangible property that includes "patents, trademarks, copyright and registered and unregistered design right". This definition needs to be clarified because intellectual property relates to pieces of information incorporated into tangible objects and at the same time copied in an unlimited quantity anywhere in the world. Here the property exists in the word not those copies, that is the information reflected in those copies. ${ }^{2}$ Among the difference forms of intellectual property, Merett ${ }^{3}$ Identified patents, trademarks and copyright as the three most important forms of intellectual property right, ${ }^{3}$ while Cromish posits that they see them as models to which aspirants will turn to for the protection of other ideas, information and trade values ${ }^{4}$. Another perspective to intellectual property law is "as the area of law which deals with legal rights associated with creative effort or commercial reputation and good will ${ }^{5}$. This definition is very important in the light of the fact of new development in modern science and technology as well as challenges, arising from the competitive nature of international global trading patterns ${ }^{6}$. It is also pertinent to add that intellectual property rights are conferred by statutes and or by common law on an individual or a corporate body with respect to the product of his works for limited period. The object of protection here is usually a work of the mind or human intellect ${ }^{7}$. Intellectual property could be categorized into two broad categories. Copyrights and industrial property. Copyrights, According to Black's Law Dictionary ${ }^{8}$, copyright is, "The right of literary property as recognized and sanctioned by positive law."Black law's Dictionary ${ }^{9}$ also defined Right as "something that is due to a person by a just Claim, Legal guarantee or moral principle" it also descried right as "a power, privilege, or immunity secured to a person by law, a legally enforceable claim that another will do or will not do a given act, a recognized and protected interest, the vocation of which is wrong copyright and industrial property Copyright is an intellectual property right that encourages individual efforts and enhance development. Copyright Act ${ }^{10}$ defined copyright simply as "copyrights under the Act" This definition appears imprecise but a closer look at the provisions provided in the Act presents copyright as the exclusive right to do or authorize the doing of certain acts in relation to the work in which the right to the work in which the right subsists such acts include, reproducing the work in any

material form, publishing the work, performing it in public, making adaptation and translation of the work ${ }^{11}$ 
Copyright encourages more authors to put their works to the public hence; there is a clear nexus between copyright and the creative industry. Copyright is intangible, it is individual owned and conferred by statute.

The above position was adopted judicially in a host of cases including, Jerrol $v$ Houston ${ }^{12}$, Corelli $v$ Gay ${ }^{13}$ and Ress $v$ Melville ${ }^{14}$ where Lord Mac Coughton defined copyright as a right that restricts others from doing a particular act."

Industrial Property is an aspect of intellectual 1 property, basically a protective right of an industrial property. They are protective rights conferring an exclusive monopoly on exploitation and is obtained upon completion of filing and registration formalities. Again industrial property could be viewed as aspect of intellectual property that excludes copyright. Industrial property include, patents to protect inventions and industrial designs, which are aesthetic creations determining the appearance of industrial products.

Industrial property could also be viewed as patents for inventions intended to protect innovation of a technical nature, designs and models aimed at protecting inventions of aesthetic nature, plant variety of right for protecting creations in the area of agricultural and also trade mark law, which reserves for the owner of the trade mark the designation under which goods and services are marketed. Industrial property also covers trademarks, service marks, layout-designs of integrated circuits, commercial names and designations as well as geographical indications and protection against unfair competition.

\section{Theoretical Framework}

Intellectual property is an intangible property. Its right could be owned and transferred, just like real property. Intellectual property right is protected by law and enforced against any form of infringement. Some scholars view its existence and enforcement as enforcing the principle of fairness while it seems objectionable to others. Against this background the study views intellectual property right through the prism of The Entitlement Theory.

Entitlement Theory: is a theory of private property created by Robert Nozick. The Theory is Nozick's attempt to described Justice in holding or what can be said about and done with the property people own when viewed from a principle of Justice.

Nozick's entitlement theory comprises three (3) main principles. ${ }^{16}$

1) A Principle of Justice in Acquisition: This principle deals with the initial acquisition of holding. It is an account of how people first come to own common property, what types of things can be held among others.

2) A principle of Justice in Transfer: This principle explains how one person can acquire holdings from another, including voluntary exchange and gifts.

A principle of Rectification of Injustice: how to deal with holdings that are unjustly acquired or transferred, whether and how much victims can be compensated? How to deal with long past transgression or injustice done by a government, among others.

One will agree that if the world were wholly just, the following inductive

definitions would exhaustively cover the subject of Justice in holding.

a) A person who acquires a holding in accordance with the principle of Justice in acquisition is entitled to that holding.

(b) A person who acquires a holding in accordance with the principle of Justice in transfer, from someone else entitled to the holding is entitled to the holding.

(c) No one is entitled to a holding except by application of $a$ and $b$.

Robert Nozick went to declare that entitlement theory would imply a distribution is just if everyone entitled to the holding they posses under distribution. Unfortunately, not everyone follows these rules "some people steal from others, or defraud them, or enslave them, seizing their product and preventing them from 
living as they choose or forcibly excludes others from competing in exchanges (Nozick 1974: $152)^{17}$. Thus the third principle of Rectification is needed.

Entitlement theory is influenced by John Lock's ideas ${ }^{18}$, under entitlement theory, people are represented as ends in themselves and equals, as Kant claimed, though different people may own or be entitled to different amounts of property. Nozicks ideas created a strong system of private property and a free market economy.

Entitlement theory could be understood better when contrasted with Rawls' "Theory of Justice, which states that each person has an equal claim to basic rights and liberties and that inequality should only be permitted to the degree that such inequality is reasonably expected to be everyone's advantage ${ }^{19}$. There is a further provision that such inequalities are only permissible insofar as there is an equality of opportunities to benefit from these inequalities. Nozick instead argues that people who have or produce certain things have rights over them on an entitlement view; production and distribution are not separable questions things come into the world already attached to people having attachment over them. Finally, Nozick believes that unjustly taking someone's holding violate their right. This idea also exist in Nigeria's legal system, for example, the dictum of Belgore J. in Oladipo Yemitan $v$ the Daily Time Nigeria Lto ${ }^{20}$ reads: "The right of a man to that which he had originally made is an corporeal right and must be protected. ${ }^{20}$ This is also true of intellectual property right which is individually owned to the exclusion of another person."

\section{Literature on the Subject Matter \\ Studies on Copyright}

Copyright is an automatic right that takes effect once the work is produced copyright encourages creators by making their products available to the wider public, no doubt there is a clear nexus between the creative industry and copyright. This idea was further expanded by Fidelis Oduah in Communication, Arts, Copyrights,
Conversion, Trespass and Defamation: $A$ Synergistic $X$-ray ${ }^{21}$. The work highlights various areas covered by copyright and highlights to the creative industry, which he described as inestimable. Odua however points out ignorance and lack of knowledge about Laws that protect intellectual property, as reasons why the general public fall into legal traps and pitfalls in pursuit of their chosen careers.

Oduah's work aims specifically at enlightening the public, especially those in creative arts and communication industries, on the availability of copyright law in our legal regime. He observes thus:

Artistic works therefore are legally protected by copyright law of Nigeria and an infringement on the artistic work of a person who has violated and /or infringed on his copyright. The artistic works eligible for copyright in Nigeria include but not limited to, paintings, drawings, etchings, lithographs, wood-cuts, prints, maps, plans, diagrams, sculptures and photographs.

He also cited the case of Savory Ltd $v$ The World of Golf $L t d^{22}$ as one of the many decided cases on copyright.

Similarly, while bemoaning the lack of awareness of intellectual property right in Nigeria Nwanna Clifford ${ }^{23}$, while acknowledging the gains of copyright laws in Nigeria highlighted some drawbacks especially in the area of implementation. The relevance of this study lies in its effort at identifying area of Weakness in the present Nigeria's Copyright Act. Nwanna also suggested area of the act that requires to be amended in order to capture recent technological developments that have taken place in this $21^{\text {st }}$ century. Obianuju Nwogu in her seminal paper "A Jurisprudential Appraisal of the subject Matter of copyright under the copyright Act", ${ }^{24}$ examines the copyright Act in Nigeria and identified some gaps. She observes that areas such as, the protection of data bases, digital library, musical and artistic works, cinematograph, film and internet copyrightable works, should be properly covered by amending the present copyright Act.

AJLLS: https://escipub.com/american-journal-of-law-and-legal-studies/ 
Nwogu's work is quite relevant and insightful to this discourse because it has specifically identified the gray areas the needs intellection in Nigeria a copyright law. Richard Seymour in $A$ New Spring for Africa's Film Industry ${ }^{25}$ attributes the recent expansion of Africa's film Industry to the introduction of relatively cheap digital technology to the consumer market, unfortunately, the same technology renders film easy for illegal copying.

Afam Ezekude ${ }^{26}$ also shares the view that there is a clear nexus between the creative industry and copyright. He identified privacy as an opportunistic virus that wears down the efforts of practioners in the creative industry, particularly visual and performing artists.

Similarly, Chioma Edoga ${ }^{27}$ in "Maximizing the Benefit of Copyright law by Visual Artists in Nigeria" attempt at creating an awareness of the protections offered by copyright Act among Nigeria artists. She avers that:

The artist will now know what legal rights and protection are entitled to his creative works; he knows the appreciation and fees owned to him by people who use his works for whatever purpose. But above all, the artist grows creatively because reward to creativity encourages creativity.

The relevance of this study lies in the fact that it serves as an eye opener to the artists, the organized art bodies, and the copyright commission and to the general public. In support of Edoga's Claim, Agbamuche-Mbu, et af8 observe.

If the protection and enforcement of intellectual property right was taken half as seriously as that of real property, you would have seen a phenomenal rise in the economic value of the creative sector in Nigeria and a corresponding increase in our GDP as proven by statistic revealed during the re-basement of our GDP which indicates that the sector is the fastest growing sector of our economy in 2013.

Copyright is not all about preventing others from using the original works of other people/authors and in so doing given him/her incentive to innovate, but it also tries to achieve a balance between protection of the authors interest and compelling public interest. Jane Mallor, James Barnes, Thomas Bowers, Michael Phillips and Arlen, Lang Vardt in their Business Law and the Regulatory Environment: Concepts and Cases ${ }^{29}$ state that,

Copyright law also tries to balance these purposes against the equally compelling public interest in the free movement of ideas, information and commerce. It does so mainly by limiting the intellectual products it protects and by allowing the fair use defence.

Indeed, the Fair Use Defence creates the designed balance and helps to make information more accessible to the public. The fair use defence to a copyright infringement suit requires the weighing of several factors whose application varies from case to case. These factors are (1) the purpose and character of the use (2) The nature of the copyrighted work (3) The amount and substantiality of the portion used in relation to the copyrighted work as a whole and (4) The effect of the use on the potential market for the copyrighted work on its value.

\section{Subject Matter of Copyright}

The subject matter of copyright refers to those works which are eligible for copyright. Eligible works are works suitable for protection under copyright law. This implies that it is not every work that enjoys protection under copyright law, in

Dick $v$. Yates, ${ }^{30}$ the court held that "a title is not long enough to constitute a literary work", In Gyles $v$ Wilcox ${ }^{31}$ it was ruled that "a fair abridgement of a work is not a copyright infringement". Lord Slesser in Hawkes \& Son (London) Itd $v$ Paramount Film service Itd ${ }^{32}$ The colonel Bogy Case, held that "infringement of copyright occurs when "a substantial, a vital and an essential part of a work is copied".

Work : in the context of copyright law includes; any translation, adaptation, new versions or 
arrangements of their content, present an original charater, ${ }^{33}$ however, there is no moral right in public domain works as was held in ShoStakovich $v$ Twentieth Century Fox Film com. ${ }^{34}$ In Alfred Bell \& Co v Catalda Fine Arts, Inc ${ }^{35}$, the court held that "variations of works in the public domain can be copyrighted if the new author contributed something more than merely trivial variation, but no large measure of novelty is necessary.

It will be pertinent to mention that copyright infringement is not theft, conversion or fraud, illegally made copies are not stolen goods. This was decision in Dowling v. United States ${ }^{36}$.

\section{Works Eligible for Copyright}

The copyright Act $35^{37}$ provides the following works/subjects are eligible for copyright: (a) Literary works, (b) musical works, (c) artistic works (d) Cinemato- graph film (e) Sound recording and (f) broadcast.

Literary Works; include (a) novels, stories and poetical works (b) plays, stage directions, film sceneries, and broadcasting scripts. (c) Choreographic works (d) computer programs (e) Text-books, treaties, histories, biographies, essays and articles (f) encyclopedia, dictionaries, directories, and anthologies ( $\mathrm{g}$ ) letters, reports and memoranda (h) Lectures, addresses and sermons.(i) Law reports, excluding decision of courts (j) Written tables or compilations.

From this it becomes clear that the Act views literary beyond works of literature, hence the inclusion of tables, compilations and computer programs as literary works.

Copyright Act are not concerned with the originality of idea, but with the expression of thought in print or writing. The originality which is required relates to the expression of the though and as regards compilation. Originality is a matter of degree depending on the amount of skill, judgment or labour that has been involved in making the compilation. Substantiality depends upon quality ration then quantity. Lord
Pearce in Ladbroke (Football) Itd $v$ William Hill (Foot ball) Itd $^{38}$ said;

The reproduction of a part which by itself has no originality will not normally be a substantial part of the copyright and therefore the courts will not hold its reproduction to be an infringement. It is this, I think which is meant by one or two judicial observations that there is no copyright in some unoriginal part of a whole that is copyright.

Similarly, in University of London press Itd $v$ University Tutorial press 1 tt $^{\beta 9}$ in a copyright claim, the test of originality which had to be passed was set out by Peterson J. saying "the word 'original' does not in this connection mean that the work must be the expression of original or inventive thought.

In Newspaper licensing Agency Itd v Marks and Spencer ${ }^{40}$ the respondent company subscribed to a cutting service but redistributed the cuttings within its offices. The cutting agency claimed that the re-distribution infringed their rights in typographical arrangement.

Musical work: it means any musical work, irrespective of musical quality and includes works composed for musical accompainment ${ }^{41}$. Typical case that illustrates this is the case of Hyperion records Itd $v$ Sawkins ${ }^{42}$. Here, the claimant had developed historical musical works for performance. They were published by the defendant by means of recordings of a performance from the scores he had prepared so called performance edition.

The issue was whether the performance editions were original and musical within the meaning of original musical work. Again, if they were, whether Hyperion had infringed Sawkins copyright and whether Swakins had copied one of the performance editions from a previous existing version and whether Hyperion had infringed Sawkins moral rights by failing to identify him as author.

The court held, while dismissing the appeal the effort, skill and time that Sawkins spent in making the performing editions was sufficient to make them original, even though they were 
based on the scores of musical works composed by Lalande. They were also musical within the meaning of CDPA. ${ }^{43}$ Copyright subsisted in Sawking performing edition and Hyperion had infringed that copyright. Hyperions claim that Sawkins had copied one edition was rejected. Hyperion had infringed Sawkins moral rights by failing to identify him as author.

Dr. Sawkins had made no new music as such he had merely worked on the old Lalande pieces in order to make them playable. But this was held to be sufficient to create an original copyright work as it had required a high degree of skill and labour.

\section{Artistic Work}

Artistic work ${ }^{44}$ includes, irrespective of artistic quality, any of the following works or works similar there to

i. Painting drawings, etching lithographs wood cuts, engraving and prints.

ii. Maps, plans and diagrammes

iii. Works of sculpture

iv. Works of architecture in the form of buildings, models and

v. Works of artistic craftsmanship and also (subject to S.I (3) of the Act) ${ }^{45}$ pictorial women tissues and articles of applied handicraft and industrial art.

An example of work constitutes an artistic work could be found in a seminal English case: Kenrick $v$ Lawrence ${ }^{46}$. Here a company held the copyright in a drawing of a hand, holding a pencil, and drawing a check-mark into a box. The drawing was used on voter cards to help the illiterate in voting. A rival company produced a card with a similar but not identical a check-mark in box. They were sued for copyright infringement. The court contemplated on how detailed and accurate an imitator must be to constitute copyright infringement. The court characterized the plaintiff claim as a claim for which copyright protection is given for a work and at which point it crosses the line from "expression" which is protected, to idea which is not. Also relevant is Walker $v$ British Picker 47 involving drawings on a parcel label have also been accorded copyright. Again in Can $v$ \& Rodney Fitch 48 it was suggested that the photographer must show some skill in arranging subject to be given copyright protection.

In Rogers $v$ Koons, ${ }^{49}$ a photographer, Rogers shot a photograph of a couple holding a line of puppies in a row and sold it for use in greeting cards and similar products a renowned artist, Jeff Koons in the process of creating an exhibit on the banality of every day, item ran across Rodgers photograph and used it to create a set of statues based on the image. Koons sold several of these structures. Rogers sued Koons for copyright. Koons responded by claiming fair use by parody. Here the court found the similarities between the two images too chose and that a typical person would be able to recognize the copy. Koons defence was rejected under the argument that he could have used a more generic source to make the same statement without copying Rogers work. Koons was forced to pay a monetary settlement to Rogers.

This case is quite significant since it is one of the famous cases that encompassed a larger issue in the art world, the issue of appropriation art can you build upon another work to create your own original pieces? And if you do so does that constitute derivative work. It also brought up the issue of photography as art, was photography just documentation, of the world or is it a creative and artistic product? Neither of these issues were answered by the case but has also become a reference used in many cases afterwards.

(c) Cinematograph film: copyright in a cinematograph film is the exclusive right to authorize the doing of the following:

Making of a copy of the film

Causing the film, in so far as it consists

Making any record embodying the recording in any part of the sound track associated with the film by utilizing such sound tracks;

Distributing to the public for commercial purpose copies of the work by way of rental, lease, hire, loan or similar arrangement. 
Copyright protection especially where nit relates to distribution of cinematographic film to the public was captured in American Motion Picture Export. $^{50}$

Sound Recording: copyright in a sound recording is the exclusive right to control in Nigeria ${ }^{51}$.

The direct or indirect reproduction, broadcasting or communication to the public of the whole or sub structural of the sound recording either in its original form or in any form recognizably derived from the original.

The distribution to the public for commercial purposes of copies of the work by way of rental, lease, hire, loan or similar arrangement in Island Records Itd ors $v$ Pandum Technical Sales and Services Itd and Anor 52

Broadcast: copyright in a broadcast is the exclusive right to control the following acts. ${ }^{53}$

(i) Recording and re-broadcasting of the whole or a substantial part of the broadcast.

(ii) Communication to the public of the whole or a substantial parts of a television broadcast either in its original form or in any form recognizably derived from the original and

(iii) Distribution to the public for commercial purposes or copies of the work, by way of rental, lease, hire, loan or similar arrangement.

In relation to television broadcast, copyright shall include the right to control the taking of still photographs from the broadcast ${ }^{54}$. Also section 44 of the copyright Act 41 allows the copyright owner to restrict importation of printed copies of his work. Then the owner of the copyright in any published literary, artistic or musical work or sound recording may give notice in writing to the Department of custom and exercise.

That he is the owner of the copyright in the work and

That he requests the Department during the period specified in the notice, to treat as prohibited goods, copies of the work to which this section applies provided that the period specified in a notice under this sub-section, shall not exceed five years and shall not extend beyond the end of the period of which the copyright is to subsist.

National Broadcasting Commission ${ }^{55}$ states that "all the public and independent broadcasting organizations in Nigeria, licensed under the relevant Laws, as well as their foreign counter parts established under Laws in force in their Jurisdiction qualify under the Act as broadcasting authorities". It is pertinent to emphasize that section 51 (1) of the copyright ${ }^{56}$ Act maintains that a re-broadcast or a broadcast or cable programs means a simultaneous or subsequent transmission or redistribution of the transmission. Mary Nwogu ${ }^{57}$ observes that "broadcast differs from other copyright works because it is transient and intangible in form despite the fact that the content of the broadcast can be reduced into or recorded in a permanent form ${ }^{44}$. It is also salient to note that many broadcasts such as live sporting events have no copyright content in all, but there is still a copyright in the broadcast itself. ${ }^{58}$ From this review, it is obvious that the copyright Act did not cover the filed with respect to the explicate protection of all subjects it is supposed to protect. These unprotected areas include databases some digital works and internet works. Meaning of certain terms relevant to intellectual property were not provided by the copyright Act there by making the Act subject to varying interpretations. All these calls for a need to amended the Act clearly state the meaning of all relevant terms appertaining to copyright.

Industrial Property Right: The law of industrial property is a uniquely part of intellectual property law and there are some types of this law which include (a) Patent (b) Design and (c) Trade mark.

Patent: A patent is a set of exclusive rights granted by a state (national government) to an inventor or their assignee for a limited period of time in exchange for a public disclosure of an invention. The gives of patent effectively gives 
the inventor or his employers, a monopoly to work the invention to the exclusion of others for a period of time not excluding 20 years (Sokefun, 59.

Bumbridge $^{60}$ posits that: Patents are the strongest form of intellectual property giving rise to a monopoly in the working of an invention either in relation to a product or a process. In Nigeria patents are governed by patents and Design $\mathrm{Act}^{61}$. Infringement of patent: An infringement has been defined by s60 PA, 1977 as the doing of any of the following things in the United Kingdom in relation to the invention without the proprietors consent.

\section{Product invention}

All inventions S25 PDA 62,1990 also defines it as the rights of a patent owner, does or causes the doing of any act which that other person is precluded from doing under section 6 of this Act, as the case may be. It is important to note that when proving infringement, the burden of proof lies with the claimant and it that are important rather than the products actually made by the claimant in Buchanan v Alba Diagnostics Ltd ${ }^{63}$, it was held that in a product invention the claim must be compared to the defendant's product. Also in Pioneer Electronics Capital Inc v Warner Manufacturing Europe $\mathrm{GmbH}(1995)^{64}$, the claimant has a patent for a process for making optical discs. There were some intermediate steps, including making stampers from which the disc could be mass-produced. It was held that the defendant had not infringed the patent because none of his discs was a direct product of the patented process and that a casual link, however important was not sufficient. In Hoechst Colanese Corp v BP Chemicals Ltd ${ }^{65}$ (1998) it was held that where the invention is a process, it may be infringed by the use of another process which occasionally extends into the parameters covered by the patent. However, in the infringement of supplying the means, this could occur where one person supplies another with a kit of parts of the latter assemble. It is important to also not that this infringement does not apply to the supply or offer to supply.
Declaration of Non-Infringement, entails making an application to the court or the comptroller of patent, by an applicant for a declaration of non infringement, in the absence of any allegation of infringement made by the proprietor if the applicant has made a request in writing asking for a written acknowledgement for such declaration and has furnished full particulars in writing ${ }^{66}$.The proprietor will however, be stopped from denying any statement and concession made there in and it is known as file wrapper.

The court has a general Jurisdiction to grant declaration of non infringement as well as application for revocation.

Evidence:_ In declaration of non-infringement, the claimant carries the burden of proof. he/she adduces the evidence and convince the court, on a balance of probabilities, that the defendant / has infringed his patent. However, Denning LJ in Ladd $v$. Marshall ${ }^{67}$ held that fresh evidence would be admitted only if special grounds existed. It is important to note that it is common to call experts to give evidence in patent cases, like in the issue of obviousness and imperatively, there is a danger of repetitious evidence and calling too many experts witnesses who essentially say the same thing. The court does not decide a case by counting how many experts each party can provide to say the same thing.

Title to Sue for Infringement: $A$ party to proceedings if found not to have title to sue, he/she will be struck from the action. This implies that the proprietor or exclusive license must have title to sue for infringement of a patent. In Bondax Carpets Itd v. Advance carpets Tiles ${ }^{68}$ the third claimant was struck out from the action. His contract with the second claimant had nothing to do with the rights under the patent. It is also important to note that one or more joint proprietor of a patent may bring an action for infringement without the oncurrence of the others, but must be made parties to the proceedings.

Categories of Infringing Act: There are two 
categories that relates to infringement of patent and they are direct and indirect infringement.

Direct Infringement: Section 60 of Patent Act, $1977^{69}$ outlines acts that constitute direct infringement of patent thus:

First, it requires that the infringing conduct be done without the patentee's consent and within the Jurisdiction covered by the Patent Act as was held in Manashe Business Mercantile Itd Williams Hill Organization Itd. ${ }^{70}$ Second, the infringing act must be done while the patent is in force and third, it should relate to process patents knowledge is required, but only as regards the offering for use of the process, not using the process

Indirect Infringement: section 60 (2) ${ }^{71}$ spelt out the conducts which amounts to infringement; these should relate to the patent and they included the following:

That the conduct is question involves supplying or offering to supply some thing tangible. Again, that something is an essential element of an invention. Also the result of the infringing act makes the invention work.

Defences to Infringement of patent:

First, there is a defence available to a person who has worked the invention before its priority date, or made effective and serious preparation to do so. Again the person might challenge the validity of the patent, claiming that it should be

revoked because it has been anticipated or that the invention is excluded matter as much as it lacks industrial application or it is invalid for lack of sufficiency.

The defendant could also claim that the patent has lapsed or expired or may challenge the claimant's title to it or his right to sue. Another defence is when the act was done privately and for purposed which are not commercial. It is also a denfence if the act was done for experimental purposes relating to the subject matter or the invention as was held in Auchin Closs $v$ Agriculture \& Veterinary_Supplies Itd ${ }^{72}$. It could also be considered as a defence if the act was done is good faith by the defendant before the priority date of the invention. Again, if the act complained of is not an infringing act, it does not fall within the meaning of infringement.

The alleged infringing products or process should posses novelty or is obvious, was held in Safety Razor co $v$ Anglo-American Trading $c 0 . L t d^{73}$. The defendant has a right to repair (sometimes referred to as an implied licence). The existence and scope of the right to repair defence was questioned in United Wire Itd $v$ Screen Repair Services (Scotland) Itd ${ }^{74}$, where this case made a distinguishing difference between repair and manufacture. It is also important to note that the doctrine of estoppels and latches may apply.

\section{Remedies to a Patent Infringement:} Remedies available for infringement of a patent include, an injunction, damages, an account of profits, an order of delivery up or destruction and declaration that the patent is valid and has been infringed by the defendant in this instance, the patent remedies has been limited to damages and or a declaration. Some of the principles applicable to an account of profit include that the claimant must take the defendant's business as it is, more principles has been laid by Laddies $\mathrm{J}$. in Celanese International Corp v BP Chemicals $I t d^{75}$. However, damages may not be available or may be limited if the patent is found to be partially valid only by section 63 of patent Act ${ }^{76}$ Also, damages and cost may not be available at all unless the court or the comptroller is satisfied that the claimant has proved that the specification was framed in good faith and with reasonable skill an knowledge ${ }^{77}$. Also in Lubrizol Corp v Esso Petroleum co ltd, ${ }^{78}$ it was held that damages may not be available or may be limited if the patent is found to be partially valid in line with 3.63 of PA. Again, damages and cost may not be available at all unless the court or comptroller is satisfied that the claimant has proved that the specification was framed in good faith and with reasonable skill and knowledge.

A limitation, however, exits on the validity of damages or an account of profits if a transaction, instilment or event by which a subsequent 
proprietor or exclusive license acquired his fights in the patent has not been registered promptly. It is also imperative to note that the grant of injunction is discretionary where the validity of the patent and the infringement are conclusively established in Coflexip SA $v$ Stolt Comex Seaway MS Itd ${ }^{79}$. The court of first instance granted an injunction and was subsequently quashed by the court of Appeal on the ground that it suffered three deficiencies. This case establishes that the purpose of an injunction is to prevent apprehended use of the patentee's statutory monopoly. Another salient issue is pertains to injunction is that of calculation of damages, which can give rise to complex considerations. However, the principle for calculation was stated in General Tyre \& Rubber co $v$ Fire stone Tyre \& Rubber co Itd $^{80}$.

Revocation of Patents: The validity of a patent may be an milled by an application, by any person including the proprietor, it could also be by putting the validity of the patent in issue or to revoke the patent in Cairn Store Itd $v$ Akiebolaget Hassles, ${ }^{81}$ it was confirmed that any person could apply for revocation founded on the basis that it is in the public interest to keep invalid monopolies off the patent register. The grounds for revocation of patent have been enumerated in s72, patent Act, $1977^{82}$ and 59 PDA $1990^{83}$ as follows: first, if the subject of patent is not patentable under section 1 of this Act or second, if the description of the invention or the claim does not conform with section $3(2)^{84}$ of this Act or Third, if for the sane invention a patent has been granted in Nigeria as the result of a prior application or an application benefiting from earlier foreign priority. $t$ is also imperative to note that a person whose application for revocation has been refused by the comptroller may apply to the court for revocation only with the permission of court, however, where revocation proceedings has been commenced but there is subsequently a settlement and the proceedings are withdrawn, it appears that the comptroller still has the power to continue considering the matter by refusing to accept the withdrawal.
In Nigeria, the PDA deals specifically with the registered design rights, without a different law for it like the United Kingdom and notably there are no provisions for the unregistered design like in the UK. An Industrial Design right is an intellectual property right that protects the visual design or objects that are purely utilitarian. In S213 (1) of the CPDA, $1988^{85}$ the design right is a property right which subsists in an Original design. In Ocular Sciences Itd $v$ Aspect Vision care $1 \mathrm{td}^{86}$ an industrial design was defined as "Consisting of the creation of a shape, configuration or composition of pattern or colour or combination of pattern and colour in three dimensional forms, containing aesthetic value." From this definition once can understand that an industrial design can be a two or three dimensional pattern used to produce a product, industrial commodity or handicraft. Again, the registered design rights cannot apply to surface decoration which is specifically excluded from the registration process. It is also important to mention that in Nigeria, the industrial Design is protected by the Patent and Design Act Cap344 LFN, 1990 otherwise known as PDA ${ }^{87}$

Under PDA, an industrial design is registrable: it is new and it is not contrary to public order or morality. A design can relate to a part only. This is important where other features of the appearance of the product are not new; do not have individual character or are otherwise excluded. It is imperative to note that there is no express requirement for eye-appeal or aesthetic quality, it is clear that appearances are important requirements.

The requirement for a design include: Novelty and individual character.

Novelty: is explained in sec 16 (2) PDA ${ }^{89}$ thus:

"A design is new if: No identical design or no design whose features differ only in immaterial details has been made available to the public before the relevant date.

However, the PDA also states in sec $13(3)^{89}$ that "an industrial design is not new if, before the date of application for registration, it has been made 
available to the public anywhere and at any time by means of description, use or in any other way, unless it is shown to the satisfaction of the Registrar that the creator of the design could not have known that it had been made so available"

Laddie J. in Household Articles Itd's Registered $D_{\text {Design" }}^{90}$ states that "if all the differences between the prior art and the design in suit are immaterial or common trade variants then the design in suit is deemed not to be novel. Immaterial details are features which make no significant visual impact on the design."

Laddie $\mathrm{J}$ further held that novel did not have to be sterling or ground breaking variety. He confirmed that novelty should be judged through the eyes of the ordinary customer or trader in the relevant goods, on other words, by someone familiar with goods of all type. To be new, the design must not have been made available to the public before the relevant date. The relevant date is the date taken to determine whether a design has been made available to the public.

Individual Character: Apart from being new, a design must also have an individual or a distinguishing character. This was best explained in sec 1B (3) of the patent Act, ${ }^{91} 1949$ (Uk) which states that a design has on individual character if:

The overall impression it produces on the informed user differs from the overall impression on such a user by any design which has been made available to the public before the relevant date.

In Wood house Uk PIc v Architectural Lightning System $^{92}$ Michael Fysh QC offered the explanation that the informed user/ was a debutante to the Pantheon of fractional Legal characters. The informed user (customer/buyer) is also important in relation to infringement, where the alleged infringing design is not identical to the protected design.

Registration:_Sec. 15 (1) of the PDA, ${ }^{93}$ states the procedure for registration of the design. The basic rule is that a design is registered as of the date on which the application was made or treated as having been made.

Ownership and Dealings: The person creating a design is known as the author of that design and the rule is that the author is entitled to be the original proprietor of the design. If the design is commissioned for money or money's worth, the person commissioning the design is the original proprietor.

If a design is made by an employer in the course of employment then the employer is treated as the original owner. The major difference as regards first ownership between registered designs and copyright is that the commissioners of designs are automatically given right of ownership of a registrable design. Usually, the person commissioning a design will be the proprietor of the registered design and will also be the owner of the design in Uk Plc $v$ Architectural Lightning Systems ${ }^{94}$ (supra), it was held that an entry of the wrong person as proprietor should not be rectified and the only way forward was to cancel the registration.

Causing a false entry to be made on the register is a criminal offence. However, knowledge that the entry is false is required for this. Therefore someone who deliberately applies to register a design knowing that he is not entitled to be the proprietor of the designs commit a criminal offence.

Duration: The initial registration period of a design is five years and registration may be renewed for a period of second, third, fourth and fifth period of five years. Under s8 (1) of the PDA ${ }^{95}$ and under the section 2004 PDA $^{96}$ registration of an industrial design (a) shall be effective in the first instance from the date of the application for registration and (b) on payment of the prescribed fee may be renewed for two further consecutive periods of five years. There is however, a period of six months grace, during which time the registration can be renewed without affecting its validity. Where there are two or more persons holding the design jointly by the leave of the Registrar, the application for restoration can be made by any one or more without joining the

AJLLS: https://escipub.com/american-journal-of-law-and-legal-studies/ 
others. The design is treated as if it had never expired.

Rights of Proprietor: The person or persons registered as proprietor can, subject to the rights vested in others of which notice is entered on the register, assign, grant license or otherwise deal with the design and give effective receipts for any consideration for any such assignment, licence or dealing.

Infringement and Exceptions: section 7A (1) $\mathrm{RDA}^{97}$, states that the right in a design is infringed by a person who without the consent of the registered proprietor does anything which falls within the exclusive rights of the registered proprietor. Section $226 \mathrm{CPDA}^{98}$ also states that the owner has the exclusive right to reproduce the design for commercial purposes. Section 25 of $\mathrm{PDA}^{99}$ states that acts that infringement the rights of a patentee or design owner are infringed if another person, without the license of the patentee or design owner, does or causes the doing of any act which that other person is precluded from doing under section 9 of this Act as the case may be ${ }^{100}$.

Exceptions: There are some acts that will not infringe the right in a registered design, some of these are:

(i) An act done for private and noncommercial purposes

(ii) An act done for experimental purposes.

(iii) An act of reproducing for teaching purposes.

(iv) The use of equipment on ship or aircraft which are registered in another country, but temporarily in the UK.

(v) The carrying out of repairs on such ships or aircraft.

Defences and Remedies: A defendant may attack the validity of the registered design on the grounds of invalidity as spelt out in section 22 of the PDA ${ }^{101}$ set out the grounds for invalidity.

Remedies:_Generally, most of the Acts on Design Law do not specifically refer to remedies of the registered design for instance, the Registered Design Act of $1949^{102}$, the patent and
Design Act. ${ }^{103}$ The RDA 104 in section 9 makes it clear that injunctions and damages are possible remedies while before its repeal, section 11B ${ }^{105}$ mentioned an account of profits.

An award of damages is not available if the defendant can show that at the time of infringement, he was not aware and had no reasonable grounds for supposing that the design was registered. If damages are not available for lack of actual or constructive awareness of the right, section 9 (2) ${ }^{106}$ makes it clear that an injunction still may be granted, an account of profit may also be available regardless of the defendant's lack of knowledge. Others may also be granted for the destruction of or for the delivery up of infringing articles ${ }^{107}$.

Unregistered Design Right: The law relating to designs in Nigeria does not in any way offer protection for designs registers in Nigeria, outside Nigeria, the Design Copyright Act ${ }^{108}$ of 1968 brought the protection for this in the United Kingdom. This concept is available to UK citizens and countries under the community designs right, but only available to citizen of other countries who have been resident in the UK for a considerable period of time.

Trademarks: This is a diverse aspect of industrial property law which encompasses several areas such as; passing off and character merchandising. Justus Sokefun (2013) ${ }^{109}$ defines Trademark as a distinctive sign or indicator used by an individual, business, organization or other legal entity to identify that the products or services to consumers with which the trademark originate from a unique source, and to distinguish its products or services from those of other entities.

A trademark is typically a name, word, phrase, logo, symbol, design, image or a combination of these elements. There is also a range of nonconventional trademarks comprising marks which do not fall into these standard categories such as those based on colour, smell or sound.

The term trademark is also used informally to refer to any distinguishing attribute by which an 
individual is readily identified, such as the well known characteristics of celebrities when trademark is used in relation to services rather than product, it may sometimes be called service mark, particularly in United States.

Registration of a trademark grants the proprietor of the mark statutory monopoly in the mark, which means the right to sue for infringement when another person uses the same or a confusingly similar mark relating to the same or similar goods or services to those covered by the registration. Distinctiveness or the marks capacity to act as an indicator of the origin of the goods or service is an essential requirement for registration. Only those or capable of acquiring distinctiveness are eligible for registration. It is this capacity to distinguish goods or services from a particular source that differentiates trade marks from other trade indicia, such as domain names and trade or company names.

The most easily registrable marks are those that are inherently distinctive such marks are otherwise meaningless, consisting of fanciful or coined words such as KODAK for film.

A trademark is an exclusive right which confers on its owner, the right to prevent some else from making use of the trademark. A definition of the word in the course of trade was given in Travelex Global and Financial Services Itd $v$ Commission, 110 the court held that the commission had not, when it adopted the official euro symbol used a sign which infringed the claimant's trademark in the course of trade.

It is important to note whether it is required that the offending sign as an indicator of origin in British sugar plc v. James Robert son \& son Itd Jacoab $\mathrm{J}$, held that descriptive use would not infringe.

Also in Arsenal Football Club Plc $v$ Reed, ${ }^{112}$ Ladie J. thought that scarves and other items bearing the football club's trademarks sold by a third party from a stall sited outside the Arsenal football ground and carrying disclaims to the effect that the goods were not official merchandise, was not use of the trademarks as indicating origin. They operated rather as badges of support for loyalty of affliiation to the trademark proprietor.

Use in Relation to Goods and Services: this phrase has not been clearly explained by the court, although one may conclude that there should be some level of proximity between the infringing sign and the product being offered to the public. In Trebor Basselt Itd $v$ the Football Association, ${ }^{113}$ a sweet manufacturer has supplied 'collectible' cards depicting members of the England Football team in its packs of sweets. The defendant's trademark (the famous three lion badge) could just be made out in some of the pictures. Rattee J. held that such incidental use was not use in relation to the sweet.

However in Beautimatic International Itd $v$ Mitchel international Pharmaceuticals Itd ${ }^{114}$ it was held that the use on invoice was in relation to the goods supplied.

Limitations and Defences in Trademark: For a trademark infringement action to succeed, the claimant should establish all the ingredients of the action. The defences opened to the defendant are found in the Act and they included:

Consent and Non- Trademark Use:_ Here the defendant may claim that what has been done is with the consent of the registered proprietor. An example can be found in Northern Shed $v$ Conde Nast ${ }^{115}$, where it was held that one licence in trademark should not the another because the later was using the mark with consent. However in the defence of non trademark use, what is trademark use now has a broader meaning than before as a result of the EC J5 ruling in the Arsenal Football Club Case ${ }^{116}$ (supra). Honest Practices: This occurs where a proprietor uses his own name, not having deliberately selected a trading name to capture good will associated with a registered trademark in NAD Electronics Inc $v$ NAD Computer System Itd, 117 the test for honest practice was equivalent to bonafide use under section 8 of the Trademark Act ${ }^{118}$. However, honest practice in the cut and thrust of 
commercial life may not necessary be bonafide in a strict sense.

Acquiescence: The proprietor's right will be limited if he has acquiesced in the use of a later registered trademark for a continuous period of five years, being aware of such use unless registration of the later trademark was applied for is bad faith.

Apart from these defences other notable ones includes, Exhaustion of Rights, Groundless Threat of infringement proceedings and comparative Advertising Groundless Threat of Infringement is an action intended to prevent heavy-handed threat being made typically to Secondary infringing goods rather than challenge the validity of the trade. In Prince PlC $v$ Prince Sports Group Inc (1998) ${ }^{119}$ here the claimant had registered 'Prince. Com'as its internet domain name. the defendant was an American company having registered ;prince' as a trademark in a number of countries including the UK. The defendant's Attorneys wrote to the claimant pointing out that its use of the domain name and claiming that the defendant was infringing the defendant's UK registered trademark. Litigation was threatened if the claimant did not assign the domain name to the defendant. The court granted a declaration and an injunction against continuous threat.

Comparative Advertising occurs when one trader compares its goods or services with those offered by other. And such comparison will usually refer to differences in price, quality or value. The comparison may be brand free or may refer directly to the trademark of the competitor, for example "washer cleaner than OMO"

In Barclays Bank PIC v RBS Advanta ${ }^{120}$ here the claimant was the proprietor of the registered trademark BARCLAY CARD, the defendant was a joint venture between the Royal Bank of Scotland and the Advanta Corp of USA, which was about to Launch credit card called RBS Advanta Visa Card. It distributed letters, leaflets contained a list of bullet points stating 15 ways the RBS Advanta Visa Card is a belter contained tables comparing the features of the RBS card with express reference. The court held that comparative advertising was allowed as long as it was honest, in this case was not in accordance with honest practices in industrial or commercial matters, or that it took unfair advantage of, or was determined to, the distinctive character or repute of the trademark.

Section 46(1) of the Trademarks Act 1994 and sec 31 (1) Trademark Act, LFN ${ }^{121}$ state that "a registered trademark may be taken off the register in respect of which it is registered on an application made by any person concerned to the court or, at the option of the applicant and subject to section 56 of the Trademark Act to the Registrar, on either of the grounds set out in subsection (2) of this section. One of the important grounds for the removal of a trademark from a register is non use of the trademark for a continuous period of five years or more. Section 46(2) of the Trademark Act ${ }^{122}$ described use in terms of revocation which includes use in a different form provided that this does not alter its distinctiveness character. While section 31 of the $1990^{123}$ Trademark Act reiterates the use of the mark, to be used bonfire.

In British Sugar Plc $v$ James Robertson Sons ${ }^{\prime} t d^{124}$. Here the court found that the claimant's "TREAT" mark was invalid as being within the absolute grounds for refusal. Jacob J. noted that having declared the mark invalid, he did not have the power to order its revocation. This means that an invalid mark would remain upon the register until such time as the proprietor failed to renew the registration. It is however important to stress that a person who has made one attack on the validity of a trademark may be stopped from making subsequent attacks as held in Hornel Foods corp. $v$ Antilles Landscape Investments $N V^{125}$

The Remedies for trademark infringement are available in respect of infringement of any other property right and they are damages, injunctions, accounts or otherwise. In Philips Electronics NV $v$ Remington Consumer 
Product ${ }^{126}$ the court held that a proprietor of a trademark which is well known may restrain by injunction the use of an identical or similar sign in respect of an identical or similar goods or services where such use is likely to cause confusion. A registered trademark is an item of personal property and an application for a trademark is also a property right, where an applicant body was dissolved without provision from ownership of the application, it will not evaporate but vest in the crown as bona vacantia. In Joel Cool (Manchester's) Ltd's Trademark Application a purported assignment was void, as Assignor Company had been dissolved before the date of the assignment. In Scandecor Develpoments $A B \quad v$ Scandecor Marketing $A B^{128}$ the court suggested that a trademark should not be regarded as liable to mislead if the origin of the goods is bare exclusive license (open ended licensee).

The internet: is a global environment and as such traders need to exercise greater care when using signs or trademarks that could, potentially, infringe trademarks registered in other jurisdictions. In Euromarkets Design Inc v Peters and Crate \& Barrels ${ }^{129}$ the defendant had a shop in Dublin and placed an advertisement on its website. Jacob J. rejected the argument that the advertisement was directed at anyone in the UK. Generally Traders using website ought to consider statements making the geographical boundary of their prospective target audience quite clear unless they do not intend to sell anywhere. They must ensure that there are no conflicting trademarks anywhere else as held in Euro-market Designs case ${ }^{130}$

Passing off is another important aspect of industrial property right. Julius Sokenfu 131 defined passing off as "a tort and can be described as a common law tort, which can be used to enforce trademark rights". The tort of passing off protects the goodwill of a trader from a misrepresentation that causes damage to the good will.

In Trebor (Nigeria) Itd $v$ Associated Industries $L t d^{132}$ in fact, the preservation of good will is the prime concern of passing off but in doing so, the protection of consumers rights are also considered, as was held in Plix Products Itd $v$ Frank M. Whinstone (Merchants) ${ }^{133}$ passing off is not only in goods/Trade or commercial Enterprise but also in charity as held in British Diabetic Association v Diabetic Society ${ }^{134}$ in Harrods Itd $v$. Harrod $L t d,{ }^{135}$ it was held that the use of another's name in relation to the provision of services could_be actionable. Also in $M c$ Cullogh $v$ Lewis A. May Ltd ${ }^{136}$ it was held that passing off may also occur in the use of individual's name or personality without permission. In Irvine Talk Sport Itd ${ }^{137}$ it was accepted that fasely implying that a celebrity was endorsing a product was actionable under passing off Design is an integral part of intellectual property that must be protected by all means possible. Design law protects the appearance of articles rather them to articles themselves in section 213 (1) of the CPDA, ${ }^{138}$ the design right was defined as "a property right which subsists in an Original Design in Ocular Sciences Itd $v$ Aspect Vision Care Ltd ${ }^{139}$ it was held that an industrial design consists of the creation of a shape, configuration of pattern or colour or combination of pattern and colour in three dimensional forms, containing aesthetic value".

Ownership in Design Right was defined in Ultra frame (UK) Ltd $v$ Fielding ${ }^{140}$-while the meaning of employees was stated in Secretary of State for Trade and Industry $v$ Bottrill ${ }^{141}$. The employer is the first owner of the design right. The meaning of employee has its well understood meaning of employment acting under a contract of service or apprentice ship.

In Secretary of State for Trade Industry $v$ Bottril/ ${ }^{12}$ Woolf LCJ took into account the fact those factors such as the degree of control exercised by the company over the shareholders employees. In Appeal Corps Itd $v$ Cooper ${ }^{143}$. it was held that the act of commissioning must come before the creation of the work, imposing an obligation of pay for the work prior to its creation. In Ultra Frame (UK) Ltd v Fielding ${ }^{143}$, 
the court held that a certain $D$ held the design rights is trust for the company through whom he was operating through whom he was operating his business at the time he created the designs.

It is however, expedient to mention that in every matter on design law, all rights occurring to the claimant and defendant are present is an unregistered right like those available in registered designs rights. The remedies that the claimant could get against the defendant are more the same with those available under other property rights.

\section{Summary}

From the available literature, it could be observed that there is no difference between industrial property and intellectual property law. The purpose of copyright law is to contribute to the development of culture, while that of industrial property law is to contribute to be development of industry. However, previous writers on the subject matter in Nigeria fail to the major difference between the two. Property right emphasize must be registered in Nigeria, with a whole lot of formalities and has number of years for it to subsist in that regard, while most of the intellectual property does not need registration, an example is trade secret which fall into public domain after the expiration of the registrable years.

\section{References}

1. J. Kur intellectual Property Law Issues in Entrepreneurial Development in Nigeria' Journal of Public and Private Law vol 6, (Awka: Faculty of Law, Nnamdi Azikiwe University);

2. Martin and J. Law Oxford Dictionary of Law, Sixth edition (eds) (New York : Oxford press, 2006) P.280

3. F. Snyllon, Studies in Industrial Property and Copyright Law (Munich:planek institute, 20003) p. 1

4. P.Merrett, Intellectual Property Law (London: Sweet and Maxwell 1996)

5. N. Cronish, Intellectual Property: Patents, Copyrights, Trademarks and Allied Rights $4^{\text {th }}$ Edition (London: Sweet and Maxwell 1999).

6. D. Bainbridge, cases and Materials in Intellectual Property Law (Johannenesburg;Pitman Publisher, 2006)p.112
7. Joseph Jarkur: Intellectual property Law Issues in Entrepreneurial Development in Nigeria Journal of public and private Law, Nnamdi Azikiwe Univeristy, Awka 2014p.194

8. A Garner. Black's Law Dictionary ( $8^{\text {th }}$ edition West Publishers, New York 1999)

9. Ibid

10. Copyright Act, cap 28 Laws of the Federation of Nigeria, 2004 s 51(1)

11. Mary Obianuju Nwogu A Jurisprudential Appraisal of the Subject Matter of Copyright Act

12. Jerrol $v$ Houston(2012) 44CY press wood Dr.410 Huston TX,77070

13. Corelli v Gray(1913) 29 TLR 570

14. Ress v Melville(1916) Mac 66

15. R Nozick, Anarchy, State and Utopia, (New York: Basic Books, 1974)

16. Ibid

17. J Rawls, A Theory of Justice, Revised ed. (Cambridge: Harvard University press 1999).

18. Oladipo Yemitan $v$ The Daily Times Nigeria Itd, 1980 FHCR (Federal High Court Report) 180 at 190.

19. Ibid

20. F. Oduah, "Communication, Arts, Copyright, Conversion, Trespass and Defamation: A Synergist $x$-Ray" Journal of the Society Nigerian Artists, Anambra, (Awka:v,2016)

21. Savory Ltd v. The World of Golf Ltd (1914)2 Ch $556(557)$

22. C. Nwanna, "Intellectual Property Law Issues in Visual Arts and Creative Industry" Journal of Environmental Sciences, Awka. Faculty of Environmental Sciences, UNIZIK., 2016)

23. Nwogu "A Jurisprudential Appraisal of the Subject Matter of Copyright Act," Journal of Public and Private Law, Faculty of Law, UNIZIK, 2014.

24. $R$ Seymor, 'A New Spring for Africa's Film Industry', African Business Magazine, London: Nov.11,2011 p.40

25. A Ezekude, A lecture on Nigerian Copyright Commission, held at UNIZIK, Awka 2016.

26. C. Edoga, 'Maximizing the Benefit of Copyright Law by Visual Artists in Nigeria' an unpublished project submitted to the Department of Fine and Applied Arts, Nnamdi Azikiwe University, Awka, 2016.

27. Agbamuche-Mbu, et al "Nigerian Entertainment Industry Urgently Needs Lawyers", an Interview with Mr. Audu Maikori in 'This Day Newspaper, Tuesday 28, July 2015,p.8

28. J Mallor et al, Business Law and Regulatory Environment: Concepts and Cases

29. J Mallor et al, Business Law and Regulatory Environment: Concepts and Cases 
30. Dick $v$ Yates (1881) 18 ch D 76

31. Gyles $v$ Wilcox (1740) 5 ATC 143.26

32. Hawkes \& Sons (London) Itd v. Paramount Film Ltd (1934) Eng.Rep.489

33. Copyright Act, Op Cit. s51 (1)

34. Shostakorich $v$. Twentieth Century Fox Film com. 1948 MISC. 67,30 NYS.2d.575 NYsnp.ct.

35. Alfred Bell \& Co. v. Catalda Fine Arts Inc. 191, F2d. 99,2d Civ, 1951

36. Dowling v United States (1985)473, U.S.207

37. Copyright Act, Op.Cit

38. Ladbroke (Football) Ltd $v$ William Hills Football Ltd(1964)WLR 273

39. University of London Press Ltd $v$ Univeristy Tutorial Press Ltd, (1916) 2 Ch.601

40. Newspaper Licensing Agency Ltd v Mark and Spencer (2001)UKHL 38

41. Copyright Act

42. Hyperion Records Ltd v. Sawking (2005)1WLR 3281

43. CDPA 1988

44. Copyright Act. Op. Cit

45. Ibid, Section 6 (1) (c) CA Cap C 28 Ibid

46. Kenrick v. Lawrence (1890) LR 25, Q.B.D

47. Walker v. British Picker (1961)RPC 78(3057-60

48. Can. v Rodney Fitch (2001) FSR 345

49. Rogers $v$. Koons (1992) F2DCR 960

50. American Motion Picture Export Co Ltd $v$ Minesota (Nig) Ltd (1981)F.H.C.R 65

51. Ibid, Section 6 (1) (c) CA. Cap 28

52. Island Records Ltd Ors v Pandum Technical Sales and Services Ltd and Anor (1993) FHC, 318

53. Ibid Section 8 (1) (a to c) CA, Cap Laws of the Federation, 2004

54. Ibid. Section 8 (2) C.A. Cap, C28 Laws of the Federation 2004

55. National Broad Casting Commission, Decree No 38, 1992, ss2(1) and 12

56. Ibid

57. M O Nwogu. Op. cit

58. Ibid

59. J Sokenfu Op. cit

60. Bambridge Op. cit

61. Patent and Design Act Cap P.2, Laws of the Federation of Nigeria

62. s25 PDA (1990)

63. Buchanan v. Alba Diagnostic Ltd (2004)UKH 5

64. Pioneer Electronics Capital Inc v. Warner Manufacturing Europe GMbH (1995)RPC 757 (CA)

65. Hoechst Colanese Corp v BP Chemicals Ltd (1998)846 F Supp.542

66. Niche Generic Ltd $v$ Land beck Vs (2004) FRS 392

67. Ladd v. Marshall(1954) EWCA CIV 1
68. Bondax Carpets Ltd v Advance Carpet Tiles (1993) FSR 162

69. Section 60 of Patent Act, 1977 Op. Cit

70. Manashe Business Mercantile Ltd v. Williams Hill Organization Ltd (2003) RPC 575

71. Patent Act Section 60 (2) Op. Cit

72. Section 60 (2) Ibid

73. 72 Auchin Closs v Agriculture \& Veterinary Supplies Ltd (1997) RPC 649

74. Safety Razor Co. v Anglo-American Trading Co Ltd (1913) 30 RPC 456

75. United Wire Ltd $v$ Screen Repair Services (Scotland) Ltd (2001) RFC 439

76. Celanese International Corp v BP Chemicals Ltd (1999) RPC 203

77. Patent Act (1977) Ibid

78. See Lubrizol Corp v Esso Petroleum co. Ltd (1998) RPC 727

79. s. 63 Patent Act Op.Cit

80. Coflexip SA v Stolt Comex Seaway MS Ltd (2001) RPC 182

81. General Trye \& Rubber Co. v Fire Stone Tyre \& Rubber Ltd (1975) PPC 203

82. Cairn Stores Ltd v Akiebolaget Hassles (2002) FSR 564

83. s.72 Patent Act Ibid

84. s. 9 PDA 1990

85. s. 3 (2) PDA Ibid

86. s.213 (1) CPDA, 1988

87. Ocular Sciences Ltd (1997) RPC 289

88. Patent and Design Act, Cap 344, LFN 1990

89. Sec. 16 (2) PDA (1990) LFN

90. 89 sec. 13 (3) PDA (1990) lbid

91. Household Articles Ltd's Registered Design (1998) FSR 676

92. Section $1 B$ (3) Patent Act, (1949, UK)

93. Woodhouse UK PIC v. Architectural Lightning System (2006)

94. Section 15 (1) PDA Ibid

95. Ibid

96. Ibid

97. Ibid

98. Section 7A (1) RDA

99. Section 226 CPDA

100. Section 25 PDA Op. Cit

101. Section 9 PDA, Ibid

102. Section 22 PDA (2004) lbid

103. Ibid

104. Ibid

105. Ibid

106. Section 11B PDA (1949) Ibid

107. Section 9 (2) RDA (2004) Ibid

108. Ibid

109. Ibid

110. Ibid 
Nwanna, Clifford Ezekwe, AJLLS, 2020 3:7

111. Travelex Global and Finacial Services Ltd $v$ Commission (2003)-T-195/00

112. British Sugar Plc v James Robert Son \& Son Ltd (1996) RPC 28

113. Arsenal Football Club Plc. v Reed (2001) RPC 922

114. Trebor Basselt Ltd $v$ the Football Association (1997) FRS 221

115. Beautimatic International Ltd $v$ Mitchel International Pharmaceuticals Ltd (200) FSR 263

116. Northern Shed $v$ Conde Nast (1995) RPC 117

$117 . \quad$ Ibid

118. NAD Electronics Inc $v$ NAD Computer System Ltd (1997) FSR 380

119. Trademark Act 1938

120. Prince Plc $v$ Prince Sports Group Inc (1998) PSR 21

121. Barclays Bank Plc v RBS Advanta (1999) RPC. 307

122. Section 46 (1) of the Trademark Act 1994

123. Section 46 (2) Ibid

124. Section 31 (1) Trademark Act LFN (1990)

125. Ibid

126. Hornel Foods Corp v Antilles Landscape Investments NV(2005) RPC 657

127. Philips Electronics NVV. Remington Consumer Product (1998) RPC 283

128. Joel Cool (Manchester's) Ltd's Trademark Application (2002) RPC 926

129. Scandecor Development $A B v$ Scandecor Marketing $A B$ (2002) FSR, 112

130. Euromarkets Design Inc $v$ Peters and Crate \& Barrels (2001) FSR, 288

131. Ibid

132. Ibid

133. Trebor (Nigeria) Ltd $v$ Associated Industries Ltd (1972) NMLR 50

134. Plix Products Ltd $v$ Frank $M$. Whinstone (Merchants) (1986) FSR 63

135. British Diabetic Association v Diabetic Society (1996) FSR

136. Harrods Ltd v.Harrod Ltd(2009)ChD FSR 115

137. MC Cullogh $v$ Lewis A May Ltd (1947) ALL ER845

138. Irvine v. Talk Sport Ltd(2003) ALL ER 881

139. Section 213 (1) of CPDA (1988)

140. Ibid

141. Ultra frame (UK) Ltd v.Fielding

142. Secretary of State for Trade and Industry v Boltrill (2000)

143. Ibid

144. Corps v. Cooper (2002) App. No,01-1867

145. Ibid

146. J. Sokenfu, Op. cit
147. C.E Nwanna, 'Intellectual Property Law Issues in Visual Arts and Creative Industry' in Joel Igbokwe et al, Land Use Transformation and Environmental Sustainability in Nigeria, (Awka: Rex Charles and Patrice publishers, 2013), p.7

AJLLS: https://escipub.com/american-journal-of-law-and-legal-studies/ 


\section{Origin of Intellectual Property Rights in Nigeria}

Legislated laws guiding intellectual property rights came into Nigeria in 1900 A.D, through the received English Laws. Since then copyright issues was governed by the English copyright Act of 1911 which was made applicable to Nigeria by virtue of an order in council which was made under Section 25 of the Act of 1911. It is however a historical paradox that even when a new copyright Act was passed in England in 1956, Nigeria still stuck to the inherited 1911 Act until 1970 when the copyright Act was promulgated as Decree No 61 of 1970.

\section{Intellectual Property Law in Nigeria}

Before 1970, inventors and Research Centers in Nigeria obtained patent for their products in Britain. The Nigeria Copyright Act of 1970 has been under constant improvement till date. For example under 1970 Act, the police could not act forcefully against the infringer and this continued until the enactment of 1988 Act with its subsequent amendments of 1992 and 1999 which made provision for the appointment of copyright inspectors with the same power as the police. The Act also created a body known as the Nigerian Copyright Commission which made the administration more effective ${ }^{7}$. What was actually contemplated in the Act was a civil suit at the instance of the owner of the copyright, with minimal criminal sanction.

However, the 1988 Act which is embodied in the Laws of the Federation has provision, where the owner of the copyright can bring a civil suit against the infringer ${ }^{8}$. Again, the copyright commission can also bring a criminal action against the infringer ${ }^{9}$. Here the sanctions are heavier than what existed in the 1970 Act. There is new a provision to commence both civil and criminal suits simultaneously. The importance of intellectual property Laws cannot be overemphasized, there is a noticeable improvement in appropriate Laws but there is also need for more effective Laws to combat privacy and other forms of intellectual right infringement which causes loss of income to the owner

There are a lot of gaps in the legal framework that regulates intellectual property right in Nigeria. This legal frame work has not changed much over the years and there is also need for continued legal education both for lawyers and the general public to follow up with global trend and know what obtains in more advanced jurisdictions.

\section{History of Design Law}

The Law of design has a reasonable long history dating back to the latter part of the eighteen century. In 1787, the first Design Act protecting designs was passed. This gave two months to designs applied for linens, calicoes and muslin. The origins of design law sprang from this.

Several other Acts were passed over the next few years and eventually, these were repealed and replaced by the patent, Design and Trademarks Act 1883. A previous distinction between ornamental and useful designs was removed and the duration of protection was set at five years. Later, the patents and Designs Act 1907 increased the maximum term $f$ protection to 15 years.

With the development of Artistic Copyright Act 1911, followed by the copyright Act, 1956 which attempted to remove the overlap between a registrable design and artistic copyright. This was modified by Design Copyright Act, 1968 which permitted dual protection to a design both as registered design and under artistic copyright.

If a design is acsthetic it was subject to some other requirements, registrable under the Registered Design Act 1949 and could be protected for 15 years. This has now been extended to 25 years. If the design was functional it was not registrable but could attract artistic copyright through its drawing. This may last for the remainder of the life of the author for 50 years.

The law of designs was radically altered by the copyright Design and patent Act 1988, both in terms of changes to the Registered Design Act 
1949 and the new unregistered design right. The law prior to the coming into force of this Act remained relevant for designs which were created or recorded before 1, August, 1989. In Nigeria, the patent and Design Act was introduced in 1968. The current legislation is the patent and Design Act LFN, Cap 344 ${ }^{10}$.

\section{Historical Evolution of Trademark}

In trademarks treatises, it is usually reported that black smiths who made swords in the Roman Empire are thought of as being the first users of trademark. Other notable trademarks that have been used for a long time include; Lowenbrau, which claims use of its lion mark since 1383, and Stella Artois, which claims use since $1366^{11}$. Another way of trademark is the branding of cattle to indicate ownership. Registered trademark involve registering the trademark with the government.

Although the history has a long way, but the law regulating it is relatively young. However, it soon because clear that this area of law needed clarification and pressure grew from traders for an effective statute which will provide for a system of registration, then the advent of the first statute which was Trademark Registration Act 1875, which established a register for trademarks and which was extremely successful, judging by the number of registration applied for.

The current statute is the trademark law of 1994 which represents a milestone in trademark law and it contains the most radical changes since the first trademark legislation in the United Kingdom ${ }^{12}$, and the Nigerian Traders got its trademark legislation alacarte and the current trademark law is Trademark Act 1990. ${ }^{13}$

\section{Historical Development of Patent Law}

It is pertinent to note that England has a prime place in world history and has actually set the mould for patent rights internationally. It is without doubt that patent has an important role to play in the industrial revolution. The origin of patent can be seen emerging in late mediaeval times. Letters patent mere open letters with the kings Great seal on the bottoms granting rights, often to foreign weaves and craftsmen, allowing them to practice their trade and overcoming guild regulations which suppressed competition. The first of such letters patent were granted in 1311 to John Rempe, a Flemish weaver who wanted to practice his trade in England, it is one of the earliest recorded instances of a patent.

Patents have existed for many years and were by no means exclusive to England. Patents in the modern sense originated in 1474, when the Republic of Venice enacted a decree that new and inventive device, once put into practice, had to be communicated to the Republic to obtain the right to prevent others from using them. This influenced the Tudor monarch who saw the system of monopolies as a way of raising revenue.

There was criticism of the over use of patent by Queen Elizabeth 1 which led to a lot of legal battles such as in Darcy $v$ Allia ${ }^{13}$. In this it case it involues, a monopoly for the making, importation and selling of playing cards. The patent was held invalid as being inter allia a common law monopoly.

Conversely, where the monopoly resulted in the acquisition of new technology, the courts were prepared to uphold the grant as valid as was held in Cloth Workers of Ipswich Case ${ }^{14}$. This was one of the cases that led to the enactment of the statue of monopolies in 1623, by parliament who were dissatisfied and regarded monopolies as bad. However, section 6 of the statute gave recognition to patents as an exception to the general rule against monopoly. Initially there was no written requirement for the description of invention to be provided by the applicant but this gradually became common practice. Like many areas of commercial law, the law of patent was primarily shaped by the nineteenth century events. Legislation was concerned exclusively with procedural improvements to the patent system thereby responding to the effect of industrial revolution. Until the early part of the twentieth century, patent were not searched for novelty, it was 
basically a deposit system with applications simply being checked for satisfactory completion.

The Act that governs the patent law is the 1977 patent Act, since the coming into effect of the Act, letters Patent are no longer issued, instead a certificate from the Comptroller General of Patents, Designs and Trade Marks is provided and the maximum time was extended to 20 years. ${ }^{15}$

However, the patent law is governed in Nigeria by the Patent and Design Act ${ }^{16}$ and the duration for a patent in Nigeria is also 20 years which is governed by section 7 of PDA 1990, so a patent expires at the end of 20 years. The Act in Nigeria follows that of England of 1977.

\section{References:}

1. A. Smith Wealth of the Nation, (Oxford: Clarendon press, 1880)

2. Justus Sokenfun, Ibid.

3. See Section 16 CA Cap C28 Laws of Federation, 2004

4. Section $20 \mathrm{lbid}$

5. Section 24 lbid

6. Patent and Design Act LFN, Cap 344

7. W. Cornish and D. Liewelyn, Intellectual Property: Patents Copyrght Trademarks and Allied Rights, Sixth Edition (London: sweet and mexmeli 2007)

8. Trade Mark Act 1990 (uk) 13. Trade Mark Act Cap 436, LFN 1990

9. Darcy v Allin (1602) 11 Co Rep $84 \mathrm{~b}$

10. See Cloth workers of IPS which case (1625)

11. Patent Act 1977

12. Patent and Design Act, Cap. 344 LFN, 1990 


\section{THE LEGAL AND FRAMEWORK OF PROPERTY RIGHT IN NIGERIA}

This chapter presents a detailed and critical examination of the legal /legislative and institutional framework of intellectual property right in Nigeria. Legislation and regulation of intellectual property right in Nigeria is imperative considering the Scio-legal issues involved in the area. Babafemi $(2007)^{1}$ captures this when he avers that:

In a country such as Nigeria the importance of the law of copyright can hardly be over emphased. This is a country where book piracy, film piracy and music piracy still reign supreme, with attendant losses of income to authors, publishers film makers, musicians and many other copyright owners. Effective laws to combat these and other copyright problems are therefore very imperative.

There is no doubt the facet that there is protection regime that covers the area of intellectual property right, but the question is, what is the situation of such protection regime?b. This question underscores the fact that the success of intellectual property as right boils down to the international conventions and. national legislation of some nations and the applicability of the international conventions in that directions. Another observable fact is that most national legislation have been enacted of amended to comply with the obligations under international conventions.

\section{National Legislation on Copyright}

The copyright Act $2004^{2}$ emanated from the $1970^{3}$ Act which was a revised version of the English copyright Act which was inherited during the colonial era. The 1970 Act was to be found obsolete and inadequate in dealing with the rising incidence of piracy and other copyright abuses. Then the copyright Law Drafting

Committee worked and came out with the copyright Decree No 47. $1988^{4}$ which later became the Copyright Act, cap 68, laws of Federation of Nigeria, 1990 and as amended by the Copyright (Amendment) Decree 1992 like other statuettes in Nigeria it is now incorporated into the laws of the federation of Nigeria, 2004.

It is truism that until 1988 when the copyright Act was passed into law, there was little or no effective administrative infrastructure for copyright practice in Nigeria. There is however, a turnaround in 1988 with the passage into law of the copyright Act. The Act provides for the establishment of a body to be known as the Nigerian copyright commission. It also provides for the establishment of a Governing Board for the Commission and the appointment of a Director-General and other supporting staff for the commission.

\section{The Nigerian Copyright Commission: Powers and Duties.}

The copyright Act of 1988 specifically enumerates the functions of Nigerian Copyright Commission ${ }^{5}$. These functions spaces that the commission shall:

Be responsible for all matters affecting copyright in Nigeria

Monitor and supervise Nigeria's position in relation to international conventions and advise the government thereon.

Advice and regulate conditions for the conclusion of bilateral and multi-lateral agreements between Nigeria and any other country.

Enlighten an effective data bank on authors and their works;

e. Maintain an effective data bank on authors and their works;

Be responsible for such other matters as relate to copyright in Nigeria.

In addition to all these responsibility mentioned above, the Nigerian copyright commission is also vested with the powers to receive and grant applications for compulsory license ${ }^{6}$. The Nigerian copyright commission is also vested with the powers of approving and registering for operation of a collecting society. The commission may also appoint copyright inspectors, as it may deem fit ${ }^{7}$. The Nigerian 
copyright commission is a body corporate with perpetual successions and a common seal and may sue and be sued in its corporate name ${ }^{5}$. Afam Ezekude, the director General of the Nigerian copyright commission ${ }^{6}$ (NCC) states that: the commission has instituted over 172 criminal cases, which are on going in High courts all over the country. There are however limitations on suit against the commission ${ }^{8}$ Thus the Act provides that no suit against the commission, a member or any staff of the commission for an act done in pursuance or execution of their duties under the Act or any other enacted law or in respect of any alleged neglect or default in the execution of this Act of any other enactment, shall lie or be instituted in any court unless the suit is commenced within twelve months next after the act, neglect of default complained of or where the damage or injury continues within twelve months next after the damage or injury cased. The Act further provides $^{9}$ that no suit shall be commenced against the commission or any member of staff of the commission before the expiration of a period of three months after a written notice. of intention to commence the suit is derived upon the commission by the intending plaintiff or his agent.

The Act ${ }^{10}$ also provides that a notice, summons, or other document required or authorized to be served by delivering the same to the DirectorGeneral at the office of the commission. There are also restrictions on execution against the property of the commission ${ }^{11}$. Hence, in any action or suit against the commission, no execution or attachment or process in the nature therefore shall be issued against the commission. However, any sum of money which is by judgment of a court awarded against thea. commission will subject to any direction given byb. the court where notice of appeal has been given by the commission in respect of the judgmentc. be paid by the commission for on its general fund.

Establishment, Membership and Functions of the Governing Board of Nigerian Copyright Commission

The Act as authorized provides" "that the commission shall have a Governing Board which shall consist of the following members:

A chairman $^{13}$ who shall be a person knowledgeable in copyright matters to be appointed by the Head of State.

b. The Director-General of the commission

One representative of the Federal Ministry of Justice

One representative of the Federal Ministry of Education.

One representative of the Nigerian Police Force One representative of the Nigerian customs service

Six other persons to be appointed by the minster who shall represent the authors in the following areas;

literary work

Artistic works

Musical works

Cinematograph films

Sound recording and

Broad casts

The Governing Board shall adopt rules governing its procedure and method of operation appointment of the Director-General and other staff of the commission.

It is provided under the copyright Act that there shall be for the commission a Director-General who will be the chief Executive ${ }^{14}$ and will be appointed by the Head of State on the recommendation of the Minister.

The Director General will be responsible for the day to day administration of the commission which shall have the power:

To appoint such other staff as it may determine To pay its staff such remence ration and allowance as it may from time to time, determine. As regards any staff in whose case it decides to do so, to pay to or in respect of such staff such pension and gratuities as are payable t persons of equivalent grade in the public service of the federation. 
The commission now has branch offices in some cities of the federation: Enugu, Kaduna, Markurdi, Owerri, Uyo, Yola and Ibadan. The minister in charge of culture has the overall control of the copyright commission; indeed, as the Act provides, the commission is responsible for such other matters as relate to copyright as the minster may, from time to time direct ${ }^{15}$.

\section{International Agreements and Treaties}

Part of the functions of the Nigerian copyright commission include (i) to monitor and supervise Nigeria's position in relation to international conventions and advise the Government thereon; (ii) to advise and regulate conditions for the conclusion of bilateral and multi lateral agreements between Nigeria and any other country.

There are indeed several treaties and international agreements on copyright to which Nigeria is a party or a signatory.

\section{Berne Convention (1886) ${ }^{16}$}

The Berne convention, adopted in 1886, deals with the protection of works and the rights of their authors. It provides creators such as authors, musicians, poets, painters among others, with the means to control how their works are used, by whom an on what terms. It is based on three basic principles and contains a series of provisions determining the minimum protection to be granted, as well as special provisions available to developing countries that want to make use of them.

The first requirement of Berne is that each member state must follow the principle of national treatment ${ }^{17}$. This is organized through the concept of the country of origin of the work. Where possible, this is the country of first publication. Where the country of origin is a Berne state, then other members must accord to work, the same treatment as they offer their own national, ${ }^{18}$ including, the right guaranteed by the Berne Convention.

The Berne convention also imposes minimum standards on its members. Accordingly, since its revision, it has outlawed any form of registration as pre-condition of legal rights ${ }^{18}$ and it requires a minimum term of the author's life and 50 year thereafter ${ }^{19}$. It also gives some recognition to the normal rights of authors. The right to authorize reproduction of a protected work is subject to a limited qualification.

\section{The Universal Copyright Convention (1952)}

The contracting states are amongst other requirements, obliged to provide for adequate and effective protection of the right of authors and other copyright owners, further published works of a national of any contracting state and works first published on that state shall enjoy in each other contracting state the same protection as that other state accords to works of its nationals first published in its own territory.

Universal Copyright Convention (UCC) was designed to assist citizens of developing countries. It was initially made in Genera in 1952, but latter raised in Paris in 1971. It is administered by United Nation Educational, Scientific and Cultural Organisation (UNESCO). It has similar provisions as the Berne Convention. In addition it does require the use of a copyright notice on a work as a pre-condition as a pre-condition to protection, the $(P)$ and its $(C$ symbols.

\section{Rome Convention ${ }^{20}$}

The Rome convention requires that each member state applies national treatment in respect of the rights which it accords to performers, second producers and broad casting organization broad casting organization, ${ }^{21}$ member states must offer those Thus in the case of records (phonograms) these include an exclusive rights to authorize all reproductions and also a right to equitable remuneration for the use of records broadcasts and public playing ${ }^{22}$. Broadcasters are to have exclusive rights over fixation, reproduction, re-broadcasting and public communication. ${ }^{23}$

\section{Trade Related Aspects Of Intellectual Property (Trip)}

An agreement entered into by the World Trade Organization to protect the trade aspect of an 
intellectual property. Some of the positive points of this agreement include, the empowerment of holders of well known marks to insist on the fair and reasonable protection of their marks, the stream liming and harmonization of the various intellectual property laws and the cooperation of state members in attempt to eliminate international trade in infringing goods.

T.R.I.P.S otherwise, Trade Related Aspect of Intellectual Property Rights provides that all members must comply with the substantive articles (1-21) of the Berne Convention, other than provision of moral rights. T.R.I.P.S makes general the Berne principle confining the extent of exceptions in national legislation to the reproduction right $^{24}$. Furthermore, computer programmes are required to be protected as literary works under Berne convention. T.R.I.P.S also has its own code of obligations relating to performers, sound-recording, producers and broadcasting organizations.

The most significant feature of the T.R.I.P.S agreement is that where a state in breach of its requirements, another displaced state may initiate the WTO dispute settlement procedure. The enforcement mechanism means that the T.R.I.P.S agreement is a more powerful force for change than the WIPO statute.

\section{World Intellectual Property Organisation (WIPO)}

WIPO, as an agency of the United Nations for the protection of rights has numerous conventions aside the Paris convention; dealing with registrable rights the organization also administers a number of conventions dealing with rights which are not registrable like copyright.

The World Intellectual Property Organization as well as adding a number of general provision to the range of the Berne Convention, also deals with on-line digital services principally be requiring, for works within the convention, (a) right of communication to the public (b) wire or wireless means which includes, the making available to the public of their works in such a way that members of the public may access these works from a place and at a time individually chosen by them. Furthermore, WIPO administers the treaties mentioned above with the United Nations Educational Scientific and Cultural Organisation (UNESCO).

The success of intellectual property as a right boils down to the international conventions and national legislation conventions and national legislation of some nations and the applicability of the international conventions in that direction. Most of the national legislations have been enacted or a mended to comply with the obligations under international conventions.

\section{References:}

1. F.O Babafemi Intellectual Property: the Law and Practice of Copyright, Trademarks, Patents and industrial Designs in Nigeria(lbadan: Justinian Brooks)

2. Copyright Act 2004

3. Copyright Act 1970

4. Copyright Decree No 47.1988

5. Section 34(3) CA as amended, Cap28, Laws of Federation, 2004

6. Fourth Schedule 47(1) as amended $\mathrm{CH}$

7. Ibid

8. See section 47 (1) lbid

9. Section 49 (1) CA as amended, Ibid

10. Section $48 \mathrm{CA}$ Ibidi

11. Section 35 CA as amended Cap C28 Laws of the Federation, 2004

12. Section 49(1) as amended Ibid

13. Section $48 \mathrm{CA}$ Ibid

14. See Section 36(2) CA as amended Cap C28 Ibid.

15. Section 34(3)(1) CA, ibid and section 43 and 50 CA Ibid. Alhaji Lai Mohammed is the current Federal minister for information and culture.

16. Berne Convention Arts 3-5

17. Ibid art 5(2)

18. Ibid, art 5(2)

19. Ibid art 9 (1)

20. Rome Convention, Art 1

21. Ibid Arts 2,3

22. Ibid Arts 5, 10012

23. Ibid Arts 4,12

24. T.R.I.P.S, Article 13 


\section{ADMINISTRATION OF INTELLECTUAL PROPERTY AND LEGAL DRAW BACKS}

\section{Jurisdiction}

The Federal High Court has been exclusive Jurisdiction over matters and disputes affecting copyright, Trade Marks, patents and industrial designs $^{1}$. Indeed, the various statutory provisions specifically vest the Federal High Court with the sole power of adjudication now laid to rest the uncertainties as to whether the state High court also has Jurisdiction over intellectual property disputes. ${ }^{2}$

\section{Courts Jurisdiction over Copyright Disputes}

The Federal High court has infringement occurred. In the case of Pamzani SA v Nigeria Cereal Processing Company Limited \& Anor ${ }^{3}$, the issue was whether the action was property filed in the Lagos Judicial Division of the Federal High Court. The $1^{\text {st }}$ defendant had filed an application under order 7 Rule 3 of the Federal High court (Civil procedure) Rules praying for an order that the suit be transferred to the Federal High Court, Kano from Lagos on the ground that the $1^{\text {st }}$ Defendant/Applicant is a company based in Kano and has its registered office there. The Plaintiff/Respondent however contended that where there were two defendants resident in more than one judicial Division, the Plaintiff could institute the action in any of the Judicial Divisions and that since one defendant resided in Lagos and the other in Kano, the plaintiff could file the action in Lagos. It was further submitted that the action should be commenced where the infringement occurred by virtue of section 15 , copyright Act, 1988.

Refusing the application of the defendant, the Federal High Court held that by virtue of order 7 Rule 4 of the Federal High Court (Civil Procedure) Rules if there are more defendants than commenced in any one of such Judicial Division subject to any order that the court may make as to convenience. The court then held that in the instant case, since one of the defendants resides in Lagos, the suit was property filed in Lagos. However one issue that usually vitiates the Jurisdiction of the Federal High Court arises where the plaintiff has no locus standi to institute the suit. If the plaintiff has no legal capacity to institute an action, the court will also have no jurisdiction to entertain the claim. The case of Musical Copyright Society Nig. Ltd $v$. Details Nigeria Limited ${ }^{4}$ indeed vary in structure. In this case the court made an Anton Piller Order in favour of the plaintiff. The defendants in the present action however asked the court to discharge the order obtained exparte on the ground that the order was obtained fraudulently. The defendants contended that relevant facts were not disclosed to the court before the order was granted and that the plaintiff had no locus standi to institute the action because he was acdlecting society which had not been registered and recognized by the Nigerian copyright commission. The plaintiff however, argued that the copyright of the works in question was vested in him and that if the right in those works was infringed by anyone, he had the Locus standi to sue. He further contended that there was no where an owner was forbidden from collecting his due compensation for the usage of his work to which copyright attached and there was no provision re-straining or compelling an owner to join any collecting society as a condition precedent to enjoying his private property. The Honourable Judge upheld the objection and went on to consider the attributes of a collecting society and to consider whether on the evidence and authorities before him the plaintiff could be truly regarded as a collecting society. In yet another case, Musical Copyright Society (Nig) Itd $v$ Ade Okin Records and $A n o{ }^{5}$, with almost similar facts as the above case, Ureje, J. after an extensive and exhaustive consideration of the legal term "Locos Standi" held that the plaintiff being a collecting society and not being registered and recognized by the Nigerian Copyright Commission could not initiate the action. The court therefore also lacked the jurisdiction to entertain the action.

As we have pointed out elsewhere, copyright will only be conferred on every work eligible for 
copyright if the author of such a work is a "qualified person" that is to say ${ }^{6}$

(a) An individual who is a citizen of, or is domiciled in Nigeria or

(b) A body corporate incorporated by or under the laws of Nigeria.

Accordingly, if you are not a Nigerian citizen or domiciled in Nigeria, you cannot succeed under this section in an action involving copyright before the Federal High Court. The court cannot exercise jurisdiction. Equally, if your company is not in corporated by or under the laws of Nigeria, the Federal High court cannot also exercise jurisdiction on any matter which the company brings and which involves copyright. We must refer to the case of Island Reocrds Ltd and Ors. $\checkmark$ Pandum Technical sales and services limited ${ }^{7}$ where six of the nine plaintiff companies were companies registered in the United Kingdom and the United States of America, the court held that it lacked Jurisdiction to entertain the suit. Similarly, in Societe BC S.A v Chagrin Industries Limited and $A$ nor ${ }^{8}$ where the plaintiff stated in its pleading that it was a French company, the court also held that it lacked jurisdiction to entertain the suit.

Having assumed jurisdiction, the courts may, after a consideration of the facts and issues of a case, grant remedies to a case, grant remedies to a succession plaintiff. Remedies for the infringement of copyright.

The available remedies are Damages, Injunction, Anton Piller order, Accounts and conversion $^{9}$ Damages: we have general and special damages, exemplary or punitive damages and nominal damages General and Special Damages

These are types of compensatory damages, General damages are losses which flow naturally from the defendants conduct and its quantum need not be pleaded or proved as it is generally presumed by law. Accordingly, evidence which will assist the court must be given if the plaintiff is to obtain substantial damages under this head of claim.
On the other hand, special damages are damages which the law does not presume but must be specifically pleased. This was emphasized in Dumas (Nig) Ltd v Ogboli ${ }^{10}$

\section{Exemplary or Punitive Damages}

This category of damages is not intended to compensate the plaintiff but to punish the defendant and to deter him from similar behavior in the future in master piece Investment Limited \& Anor $v$ World Wide Media Limited and Ors. Odunowo J. said",

on a claim for exemplary or punitive damages, the trend of both Judicial and Juristic opinion is that the court may award additional damages for such matters as the authors reputation of feeling, the vulgarization of the work, economic loss, unjust enrichment by the defendant as a result of the act of infringement, the conduct of the defendant and the means of the parties etc. nonetheless, the amount excessive is the only qualification and the discretion vested in the court in this regard must, as usual be exercised both judicially and judiciously in the interest of peace. It is pertinent to refer her to section 16 (4) of the copyright Act which provide that where in an action under this section, as infringement of copyright is proved or admitted and the court in which the action is brought having regard (apart from all other material considerations).

a) The flagrancy of the infringement is defendant by reason of the infringement is satisfied that effective relief would not otherwise be available to the plaintiff, the court in assessing damages for the infringement shall have power

to award such additional damages by virtue of this sub-section as the court may consider appropriate in the circumstances

It is possible that the above sub-section contemplates the award of aggravated or exemplary damages, as discussed above.

\section{Norminal Damages}

These are awarded in those cases where the plaintiff establishes a violation of his right by the defendant but he is unable to show that he 
suffered any actual damages as a result of defendant's wrong doing.

Norminal damages may also be awarded where damages has been proved but no evidence has been given as to its extent so that the assessment of compensatory damages is impossible ${ }^{11}$. The case of Yemitan $v$ The Daily Time (Nig) Ltd \& Anor ${ }^{12}$ is also very instructive on the issue of damages. In this case, the plaintiff claimed damages from the defendants for infringement of his copyright in an article entitled "The day the Lagoon Caught Fire", which was published in the Nigerian Magazine No 79 of December, 1963. He was able to prove that the article was reproduced verbatim in the "Headlines" of No 52 of July, 1977 without the consent or permission. The $1^{\text {st }}$ defendant was the publisher of the "Headlines" while the $2^{\text {nd }}$ defendant was the Editor at the material time. Although the defendants denied liability of the plaintiffs claim in their statement of defence, their counsel conceded during the trial that the plaintiff's copyright was infringed by the defendants in the issue of the said "Head-Lines". The plaintiff did not prove any special damage. The court stated that in an action for infringement of copyright proof of actual damage is not necessary. Damages indeed are said to be at large. The court stated further that in awarding exemplary damages in action for infringement of copyright, the court should consider (a) the flagrancy of the infringement and (b) any benefit shown to have accrued to the defendant by reason of the infringement. ${ }^{13}$ The court awarded in favour of the plaintiff $\mathrm{N} 10,000.00$ for the infringement of his copyright and an additional N15,000.00 exemplary damages.

\section{Injunctions}

One remedy that is usually granted by the courts to a plaintiff under the statutory provision is that of injunction. Since damages may not always be adequate, an injunction is usually an added remedy. It is granted by the court to prevent a person from doing or continuing to do a wrong. An injunction can be granted before trial upon affidavit evidence or even urgent need to stop an infringement. It is also possible to obtain an injunction to prevent the commission of a threatened infringement. An injunction shall however not be issued in proceedings for the infringement of copyright which requires a complete or partly completed building to be demolished or prevents the completion of a partly completed building ${ }^{14}$. In Yemitan \& Daily Times ${ }^{15}$ (Supra) the court granted a perpetual injunction against the defendants from any further sale, use or dealing in plaintiff work.

Anton Piller Order. An Anton Piller Order is an order which will enable the claimant, accompanied by his solicitors and law enforcement agents and court bailiff to enter the premises where articles are kept and remove them or have copies made, so they can be produced at the trial. It is an order, which is obtained without notice to the other party, so as to remove evidence which ought to otherwise be destroyed. The order originated in Lord Dennings Judgment in the case of Aton Piller $K$ $G \vee$ Manufacturing Processes $L t^{16}{ }^{16}$. The object of a search order in this context is the preservation of evidence. In this instance, the claimant has to give an undertaking as to damages in case he is wrong and the defendant suffers damages as a result of granting and execution of the order.

The purpose of the order is to fulfill a legitimate purpose that is protecting the claimant's copyright ${ }^{17}$. It is imperative to note that search orders have been abused in their exercise in the past. For this reason, they are granted sparingly and with strict compliance with guidelines set down in Universal Thermosensors Ltd $v$ Hibben 18

\section{Account of Profits}

Equity provides an alternative to damages in the order for an account of profits. The infringer may have made a profit from his actions which exceeds in value what would be the normal award of damages. The purpose of the remedy is to prevent unjust enrichment of the defendant ${ }^{19}$. The quantum of an account is the profit, that is the gain made by the defendant 
attributable to the infringement and not the wholesale or retail value of the offending material. Unlike ordinary damages accounts are available regardless of the defendants knowledge as to whether copyright subsisted in the work. A claimant cannot have both damages and an account of profits, but must elect between them. However, they do not have to do so, until after the conclusion of the trial ${ }^{20}$

\section{Rights of Conversion}

Conversion rights are also available to party whose rights have been infringed. The copyright Act provides that 21

All infringing copies of any work in which copyright subsists, or of any substantial part thereof, and all plates, master tapes, machine, equipment or contrivances used, or intended to be used for the production of such infringing copies shall be deemed to be property of the owner, assignee or exclusive licensee as the case may be, of the copyright who accordingly may be of the copyright who accordingly may take proceeding for the recovery of the possession there of or in respect of conversion thereof.

In conclusion, the successful claimant has wide option of remedies to choose in case of an infringement of his copyright. The remedies available for copyright infringement are only compensatory in nature and cannot in its entirety remove the pain caused by the infringement.

\section{Drawbacks in Litigating Intellectual Property Cases in Nigeria}

Generally speaking, Nigerian Judiciary system is still be deviled with some problems which include the fact that there is no rapid progression in trying criminal cases, infact delivery of justice in Nigeria could still be seen as delayed. Again the conduct of some lawyers in the course of their business still fall below expectation.

Pertaining litigating intellectual property cases in Nigeria, first, it is pertinent to reiterate that the courts of first instance in such matters under Nigerian Law are the Federal High Courts. This notwithstanding, Nigerian courts always present a frustrating scenario, even if you have diligent counsels and a very competent judge, the very technical and complex procedural nature of civil litigation a system that can frustrate such a matter.

Another biting issue is that of piracy which takes place in Nigeria and sometimes with offenders operating outside the jurisdiction of intellectual property owner. Such theft of intellectual property which often involves cyber crimes should be referred to international treaties such as Berne Convention Treaty which Nigeria is a signatory to, for mutual legal assistance, but one discovers that this avenue is seldom explored when such cases arise.

There is also no specialized courts that focuses solely on intellectual property related matters. This is necessary because the peculiar nature of the field demands that such matters should be dispensed with summarily and not to go through the same long winded process, which could only delay Justice; Justice delayed is Justice denied.

\section{References:}

1. Section 46 C.A Cap (28, However an appeal lies from the decision of Federal High Court to the court of Appeal and from the court of Appeal to the supreme court.

2. See Senora Gentil v Tabansi Agencies(1977) CCH 2471, Jamal Steel structures Ltd v ACB Ltd (1993) I ALL N.L.R Pt2

3. Pamzani S.A. $v$ Nigeria Cereals Processing Company Limited \& Anor F.H.C.R.191

4. Musical Copyrigh Society Nig. Ltd $v$ Details Nigeria Limited (1996) F.H.C.L.R 473

5. Musical Copyright Society Nig Ltd vAde Okin Records and Anors (1997) F.H.C.I.R. 313

6. Section 2(1) Copyright Act

7. Island Records and ors v. Pandum Technical sales and services Limited (1995) F.H.C.L.R 318

8. Societe Bic S.A v Chargin Industries Limited and Anor (1997) F.H.C.L.R 727

9. See Cornish and Liewellyn, Intellectual Property, $5^{\text {th }}$ Ed pp. 66-80

10. Dumas (Nig) Ltd v. Ogboli (1973) 3 UILR 305 at p. 311 (1973) 3.3.c-196 at 204, 205

11. See Plateau Publishing Co v Adophy (1986) 4, N.W.L.R 265, where the court awarded damages of N25,000.00 (Twenty-five Thousand Naira) to the complainant. 
Nwanna, Clifford Ezekwe, AJLLS, 2020 3:7

12. O. Yemitan $v$ The Daily Times (Nig) Itd \& Anor (1980) F.H.C.L.R 186

13. See Williams v. Settle (1960)2 A L L E.P.806

14. Section 16(5) CA Cap C28, Laws of the Federation of 2004

15. Ibid

16. Aton Piller KG v Manufacturing Processes Ltd (1976) ICH 55

17. See Columbia Pictures v Robinson (1987) ICH 38

18. Universal Thermosensors Ltd $v$ Hibben (1992) 3 ALLER 257

19. See Potten Ltd $v$ Yorkshire Ltd (1990) FSR 11

20. Island Records $v$ Tring (1995) FSR 566

21. Copyright Act, 52 


\section{SUMMARY, CONCLUSION RECOMMENDATION}

\section{Summary}

This study examined intellectual property right in Nigeria; it took a deep look at its legal framework, Administration and challenges facing litigating cases under intellectual property law in Nigeria. The law of intellectual property is universal and its origin dates several centuries ago. Its aim is to protect the rights of owners; intellectual property law therefore has a unique and peculiar nature. It protects what is referred to as 'chose in action'.

Intellectual property law protects the moral and economic rights of the author form being infringed by an unauthorized person. As a developing area of law in Nigeria, reliance is placed on foreign laws (particularly English authorities) because of the dearth of Nigerian authorities.

It is hoped that researches such as this will help to create the needed awareness by all and sundry of this area of law, which could stem considerably, the ever-rising trend of piracy, particularly in the book, music and film industries. Also trademarks and trade names malpractices, inventors and industrial designers will be able also to reap fully the fruits of their inventions and creations.

\section{Conclusion}

This study covers issues and problems of two main aspects intellectual property law: copyright law and industrial property law. The importance of legislating and enforcement of intellectual property laws can never be over emphasized. Nigerian manufacturers were losing billions of naira through trademarks and trade names malpractices. Sometime ago, the President of the Manufacturers Association of Nigeria disclosed that most of the fake products bearing the trade mark of genuine manufacturers were smuggled into Nigeria from foreign countries ${ }^{2}$.

Again, the Nigerian entertainment industry conjures a picture of a huge gold mine that is present underutilized and this study advances a proper enthronement of intellectual property law as a means of achieving that goal. The major draw back of this industry is piracy.

Apart from piracy, one could observe various frustrations that trail litigations in Nigerian courts especially cases in intellectual property. It is obvious that the present laws governing intellectual property in Nigeria requires modification. Despite some of the limitation in the law governing intellectual property rights in Nigeria, the paper observes that there are still sufficient provisions within the law to protect this right, while hoping that it will be updated and some out dated sections repealed.

\section{Recommendations}

In view of the issues raised in this research, the study calls on manufacturers, inventors and people in the creative industry to be pro-active on issues of intellectual property in the pursuit of their day to day business.

Government should also enact more specific legislation to take care of the rapid changes in digital, media technology and creative sectors. Again while modifying the legislation, meaning of all relevant terms appertaining to intellectual property right should be stated clearly to avoid ambiguity.

Special courts should be set up, which will focus solely on intellectual property related matters there is need for a special unit in the Nigerian Police Force or outside the force, that should not only confiscate products but also have the legal teeth to bite and not only bark in this war against piracy.

Finally, there are observable gaps in the rules of professional conduct in the Bar. The legal profession has endured for a long time but the legal frame work has not changed much. There is need for continued legal education for lawyers, to enable trends and have knowledge of what happens in other jurisdictions. 


\section{BIBLIOGRAPHY}

\section{Books}

Babafemi, F.O Intellectual Property, the Law and Practice of Copyright Trademarks, Patents and Industrial Designs in Nigeria (Ibadan: Justinan Books Ltd, 2006)

Banbridge, D. Cases and Materials in Intellectual Property Law (Johannesburg: Pitman publishers, 2006) p. 112 Cornish, W and Liewelyn, D. Intellectual Property: Patents, Copyrights, Trade marks and Aliied Rights, sixth Edition (London: sweet and Maxwell, 2007)

Garner's Black Law Dictionary, $8^{\text {th }}$ edition, (New York: west publishers, 1999)

Mallor et J. et al, Business Law, Concept and Cases (New York: pitman publishers, 2015)

Merreth, P. Intellectual Property Law (London: Sweet and Maxwell, 1996)

Nozick, R. Anarchy, state and topic (New York: Basic Books, 1974)

Oxford Dictionary of Law, sixth edition Martin and Jonathan Law (eds) NewYork: Oxford press, 2016) P: 280

Rawls, J. A Theory of Justice, Revised edition, (Cambridge: Harvard University Press, 1999)

Shyllon, F. Studies in industrial Property and Copyright Law (Munich: Planek Institute, 2013) p.1

Smith, A. Wealth of Nations (oxford: Clarendon Press 1880)

Sokenfun, J. Intellectual Property II Lagos: National Open University of Nigeria, 2015) p.14

\section{Journal Articles}

Kur, J. 'Intellectual Property in Nigeria,' Journal of Public and Private Law, vol Azikiwe University 2014) p.194

Nwanna, C. 'Intellectual Property Law Issues in Visual Arts and Creative Sciences (Awka: Faculty of Environmental Sciences, UNIZIK, 2016)p3

Nwogu, O.M.A Jurisprudential Apprasial of the subject Matter of Copyrigh Act; Journal of Public and Private Law(Awka: Faculty of Law, UNIZIK, 2014)

Oduah, F.Communication, Arts Copyright, Conversion, Tresspass, and Defamation: A Synergist x-Ray' Journal of the Society of Nigerian Artists (Awka: SNA, Awka Chapter, 2016)

Seri, A. Property and Hunger; Twenty Questions: An introduction to philosophy (Belmont: Waitworth, 2015)

\section{Unpublished works}

Edoga, C. Maximizing the Benefit of Copyright Law by Visual Artists in Nigeria, an Unpublished project submitted to the Department of Fine and Applied

Arts, Nnamdi Azikiwe University, Awka 2016

Ezekude, A. Intellectual Property Right in Nigeria: Copyright, a lecture held at Nnamdi Azikiwe Univeristy Awka on 12 April, 2016

\section{Magazine/Newspaper Publications}

Agbamuche-Mbu, C. et al, 'Nigeria Entertainment Industry Urgently Needs Lagos Thursday, $28^{\text {th }}$ July, 2015, p.8

Seynor, R A New Spring for Africans Film Industry', African Magazine, $\quad$ (London's $\quad$ November 2011)p45

\section{TABLE OF CASES}

Alfred Bell \& co v Catalda Fine Arts Inc,(1951) 191, F2d. 99. 29. C.V,

American Motion Pictures Exports Co Itd $v$ Minesota (Nig) Itd

(1981) EH. CR65 17

Arsenal Football club Plc v Reed (2001) RPC 922..............................32

Aton Piller K G v Manufacturing Process Ltd (1976) ch 55.....................61

Auchinclass $v$ Agriculture \& Vetenary Supplies Ltd (1977) RPC 649.............23

Barclays Bank PIc v RBC Advanta (1996) RPC 307.

Beautimatic International Ltd $v$ Mitchell International Pharmaceuticals Ltd

(2000) FSR 263.

Bondex Carpet Ltd v Advance Carpets Tiles (1993) FSR 162 
British Diabetic Association v Diabetic Society (1996) FSR 122..................37

British Sugar Plc v James Robertson Sons Ltd (1996) RPC 28.................32

Buchana v Alba Diagnostic Ltd (2004) UKH5.............................20

Can v Rodney Fitch (2001) ECDR. 5..................................... 16

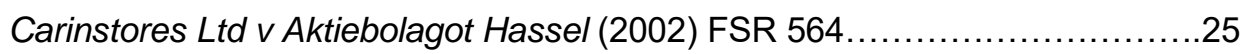

Celanese International Corp v B.P Chemicals Ltd (1999) RPC 182...............24

Coflexip S A v Stolt Comex Seaway MS Ltd (2001) RPC 182..................24

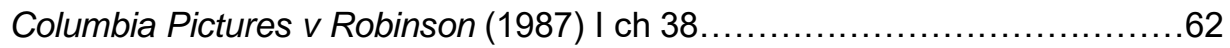

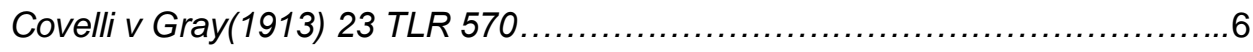

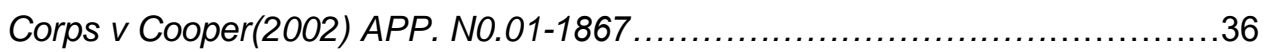

Cow (PB) \& co Ltd v Common Rubber Manufacturing Ltd (1959)

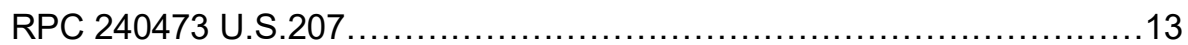

Cloth Workers of Ipswhich(1625) .................................46

Dacy $v$ Allen (1602) 11 co Rep.84 b......................................46

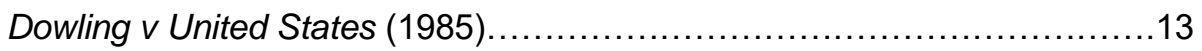

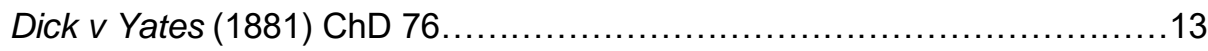

Dumas (Nig) Itd v Ogboli (1972) 3 U.I.L.R 305 at P.311 ......................59

Euromarket Design Inc v Peters and Crate \& Barrels (2001) FSR, 288...........36

General Tyre \& Rubber Co v Firestone Tyre \& Rubber Ltd (1975) RPC 203....24

Gyles $v$ Wilcox (1740) s ATC 143.26..................................... 13

Hawkes \& Sons (London) Ltd v Paramount Film Ltd (1934) Eng. Rep 48c.....13

Hoechest Colanese Core v RP Chemicals Ltd (1998) 846 F Supp.542..........20

Hornel Foods corp v Antilles Landscape investments NV (2005) RPC 657........35

Harvods Ltd v Harrold Ltd(2009)ChD FSR 11.......................... 37

Household Articles Ltd $v$ Registered Design (1998) FSR 676....................27

Hyperion Records Ltd v Sawking (2005)1, WLR $3281 \ldots \ldots \ldots \ldots \ldots \ldots \ldots \ldots \ldots \ldots$

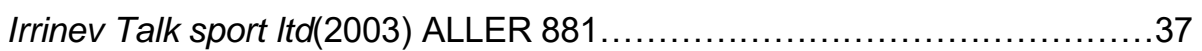

Island Records Ltd ors $v$ Pandum Technical Sales and services and

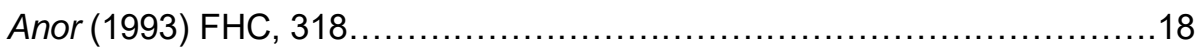

Island Records $v$ Tring (1995) FSR 566...............................62

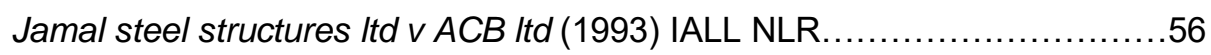

Jerrol v. Houston (2012) 14-11-0031CV,14-11-00496CV....................6

Joel Cool (Manchester) Ltd v Trademark Application (2002) RPC 926...........36

Kenrick v Lawrence (1890) LR 25 Q.B.D....................................

Lad v Mashall (1954) EWCA CIV .....................................21

Ladbroke (Foot ball) Ltd $v$ William Hills Football Ltd(1964)WLR273.............14

Lubrized Corp v Esso Petrleum co Ltd (1998) RPC 727

Manashe Business Mercantile Ltd $v$ Williams Hill Organization Ltd

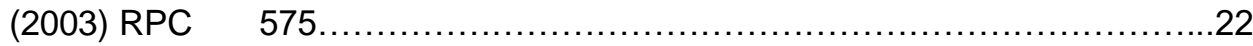

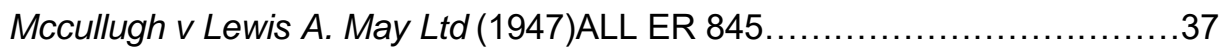

Musical Copyright Society (Nig) Ltd $v$ Ade Okin Records and Anors (1997) F.H.C.C.R. 313 57

NAD Electronics Inc v NAD Computer System Ltd (1997) FSR 380. 33

Newspaper Licensing Agency Ltd Mark and Spencer (2001) UKHL38. 14

AJLLS: https://escipub.com/american-journal-of-law-and-legal-studies/ 
Niche Generic Ltd $v$ Landbeck NS (2004) FRS 392 .........................21

Northenshed $v$ Conde vast (1995) RPC 117 ..............................33

Ocular Sciences $L t d \mathrm{v}$ Aspect vision care Itd................................33

Oladipo Yemitan $v$ The Daily Times Nigeria Ltd, (1980) FHCR (Federal High Court Report) 180 at 190. 60

Panzani S.A. $v$ Nigerian Cereals Processing Company Limited \& Anor FHCR .................................................................. 56

Phillips Electronic NU v Remington Consumer Products (1998) RPC 283.........35

Pioneer Electronics Capital Inc v Warner Manufacturing Europe Gabit

(1995) RPC 757 (CA). 20

Plateau Publishing co v Adophy (1986) 4 N.W.L.R 265........................60

Plix Products Ltd v Frank M. Whinstone (Merchants) (1986) FSR 63..............37

Potten Ltd v Yorkshire Itd (1990) FSR11 .................................62

Prince Plc v Prince Sports Group Inc (1988) FSR 21 .............................34

Ress v Melvile(1916)Mac66............................................

Rogers $v$ Koons(1992) 960f2dcr..............................................

Safety Razor co v Anglo-American Trading co Ltd (1913) 30 RPC 450............23

Savory Ltd $v$ The World of Golf Ltd (1914)2ch556(557)....................... 10

Scandecor Development AB v Scandecor Marketing A B (2012) FSR 112........36

Secretary of State for Trade and Industry v Bottrill (1999)EWCA Civ,781 ......37

Scnora Gentil v Tabansi Agencies (1977) C C H 2471 ..........................56

Shostakorich v. Twentieth century FOX (1948)196 MISC.67.30NYS...........13

Society B/C SA v Chagin industries Limited and Anor (1997) F.H.C LR 727 .....58

Travelex Global and Financial Services Ltd v Commission (2003)-T-195......100

Trebor (Nigeria) Ltd v Associated Industries Ltd (1972) NMLR 50...........32, 37

Ultraframe (UK) Ltd $v$ Fielding(2005)ChD11 .............................. 37

United wire Ltd $v$ Screen Repair Services (Scotland) Ltd (2001) RFC 439........23

University of London Press Ltd v University Tutorial Press Ltd(1916)2ch.601 ....14

Willians $v$ Settle (1960) 2 ALLER 806. 61

TABLE OF STATUTES

SECTION A COPYRIGHT ACT

Statutes U.K

Page

1710 Copyright Act S.11

.

1734 Engraving Copyright Act

U. K ..1

1766 Engraving Copyright Act

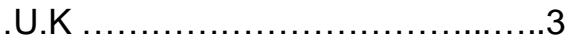

1777 Engraving Copyright Act. U. K. ..U.K. 581787 Copyright Act 58

1794 Copyright Act U.K .58

1798 Sculpture Act U.K 281814 Copyright Act S.4

U.K 42

1836 Engraving Copyright Act

U.K 31842 Literary Copyright Act S .3. U K ...41862 Fine Arts Copyright At. U.

$\mathrm{K}$. 31911 Common Law Copyright Act S. 31.

U.K. .62

1970 Nigerian Copyright Act S. 2 (embodied in Cap. C28 Laws of the Federation, 2004). 61

AJLLS: https://escipub.com/american-journal-of-law-and-legal-studies/ 
Nwanna, Clifford Ezekwe, AJLLS, 2020 3:7

S.2(a)

(b).

S.3(1)

14

S.5(1)

15

S.10(3). 17

S.11(1) .18

S.19(1). 18

61 18 Schedule 2 Act

1988 Nigerian Copyright Act S.1(1) (embodied in Cap C.28 Laws of the Federation, 2004 61

(2). 10

(b). 17

S.2 First Schedule 42

1988 Nigeria Copyright Act S.2(1) (embodied in Cap. C28 Laws of the Federation, 2004)

5

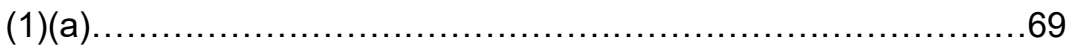

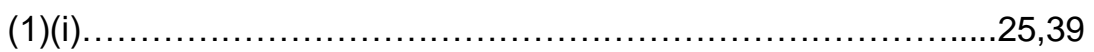

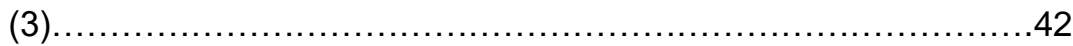

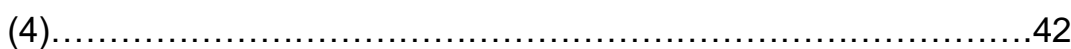

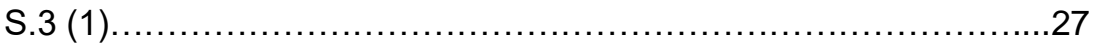

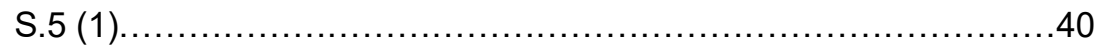

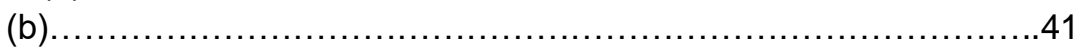

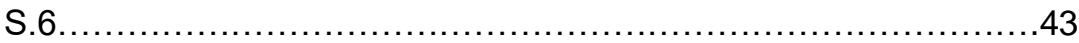

S.6(1) Second Schedule

$43,45,47,54$

(1) (b). 44

(3).

Schedule (amended para. 1.9. 59 .44 S.6(4) $3^{\text {rd }}$ $3^{\text {rd }}$ Schedule (amended para. 1(a)-(d) .60

$3^{\text {rd }}$ Schedule (amended para.2). 60 $3^{\text {rd }}$ Schedule (amended para.3) 61

$3^{\text {rd }}$ Schedule (amended para.4) ......................................61

$3^{\text {rd }}$ Schedule (amended para.5(a)-(c)..............................62

$3^{\text {rd }}$ Schedule (amended para.6...................................62

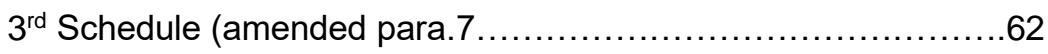

$3^{\text {rd }}$ Schedule (amended para.8(a)-(b) .............................63

$3^{\text {rd }}$ Schedule (amended para.9....................................63

S.7

(1)... 45 59

S.8 (1) .46

(2) 46

(3). .59

S.9

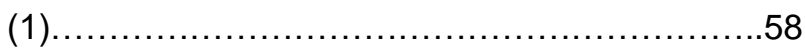

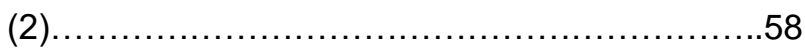

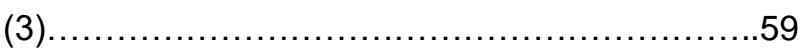

S.10

(2) (a) 30

(b). 27

AJLLS: https://escipub.com/american-journal-of-law-and-legal-studies/ 
Nwanna, Clifford Ezekwe, AJLLS, 2020 3:7

(3). .30

1988 Nigeria Copyright Act S. 10(4) (embodied in Cap. C28 Laws of the Federation, 2004). 30

(5) 39

S.11(1) 30

(2).

(3) 31,34

(4) .34

(5). 38

(6). .38

(7). 38

(8). .30

S.12

5,72

(a). .41

1988 Nigeria Copyright Act S. 34(3) (f) (embodied in Cap. C28 Laws of the Federal, 2004). 98
S. 35 .5
S. 37 . .5

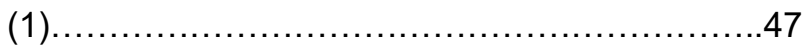

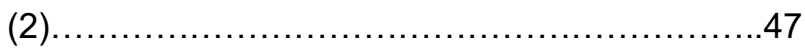

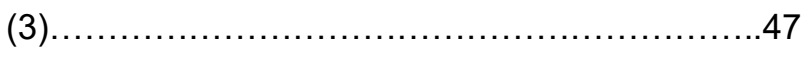

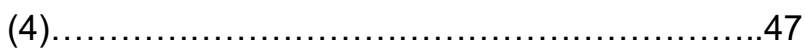

S. 39. .31

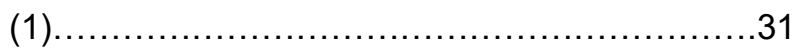

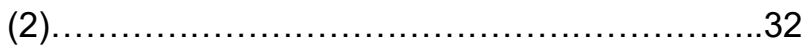

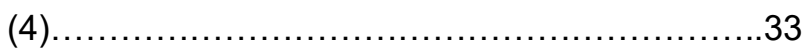

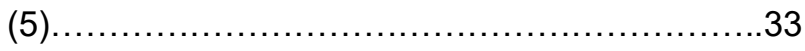

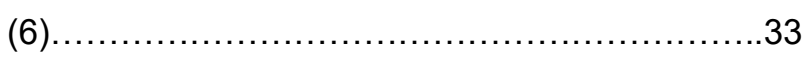

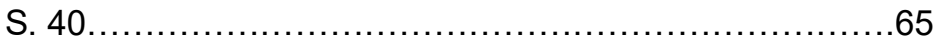

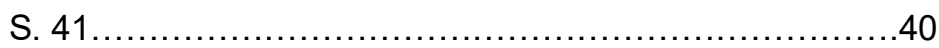

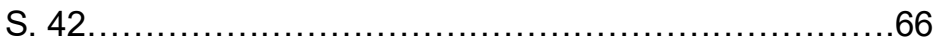

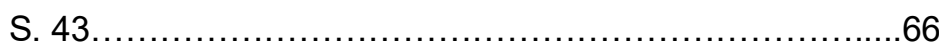

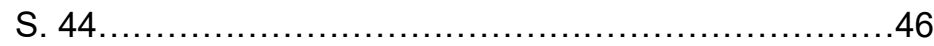

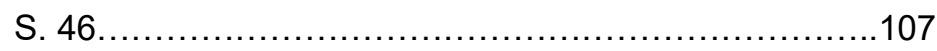

S. $47(1)$ (as amended).....................................95

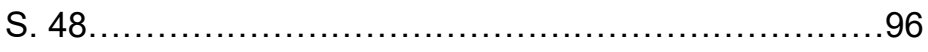

S. 49(1) (as amended).................................... 96

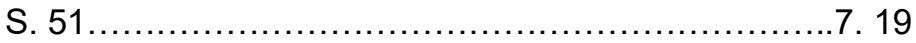

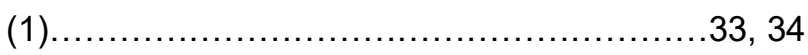

$4^{\text {th }}$ Schedule paragraph $2(1) \ldots \ldots \ldots \ldots \ldots \ldots \ldots . \ldots 4,95$

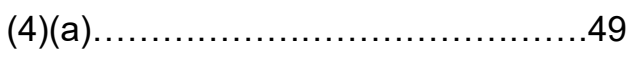

(b) ................................49

1988 Nigeria Copyright Act $4^{\text {th }}$ Schedule paragraph 2(7)@ (embodied in Cap. C28 Laws of the Federation, (2004). 48,49

(d). .49

AJLLS: https://escipub.com/american-journal-of-law-and-legal-studies/ 


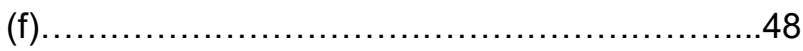

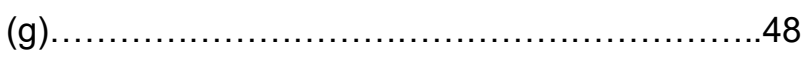

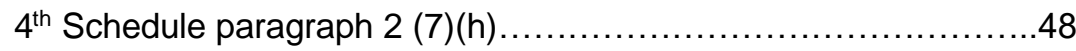

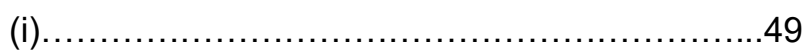

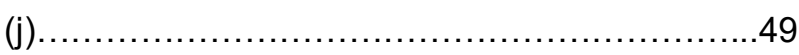

Paragraph 3 (1)

51

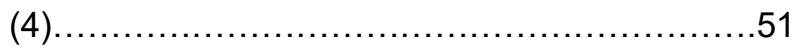

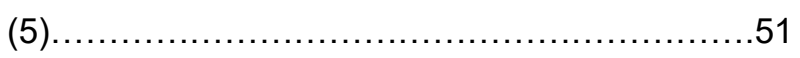

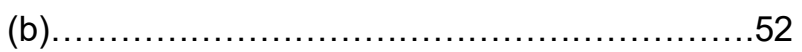

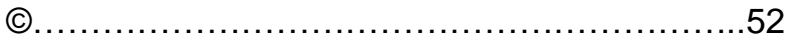

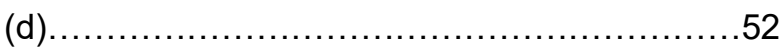

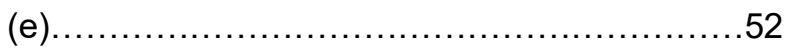

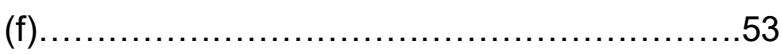

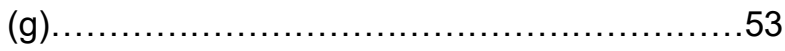

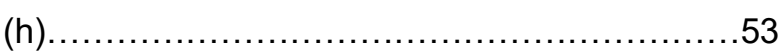

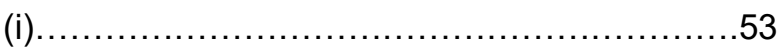

Paragraph 4 (1)(a) ........................................ 49

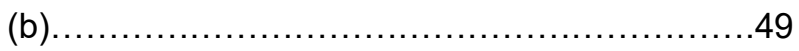

\section{SECTION B-TRADE MARKS ACT}

\section{Statutes}

1875 Trade Marks Regulation Act U.K.............................45

1876 Trade Marks Regulation (Amended) ... U.K..........................45

1877 Trade Marks Regulation (Amended) …......................................46

1883 Trade Marks Act S. 10 ....................................................46

1888 Trade Marks Act .........................................................47

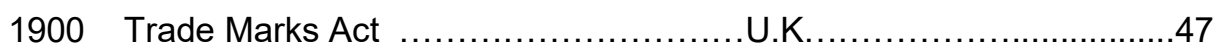

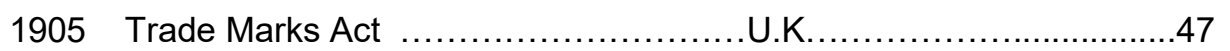

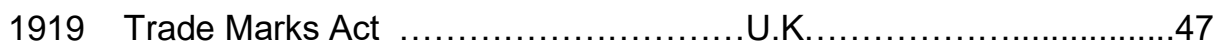

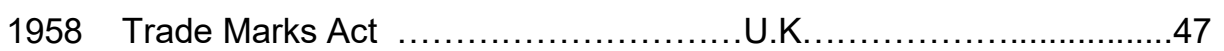

1919 Trade Marks Act S. 1 (1) embodied in Cap. T 13 Laws of the

Federation 2004)

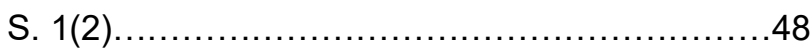

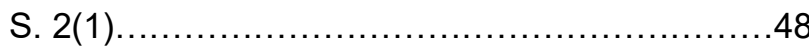

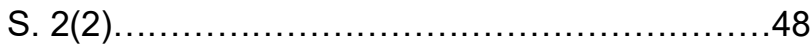

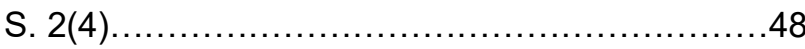

1965 Trade Marks Act S. 10(1) (embodied in Cap. T12 Laws of the Federation 2004 49

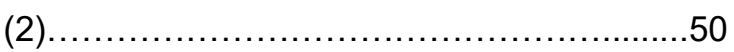

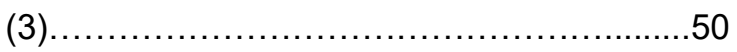

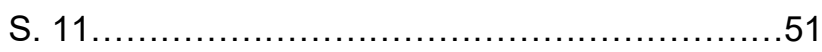

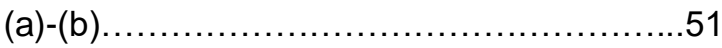

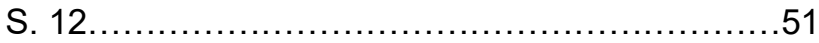


Nwanna, Clifford Ezekwe, AJLLS, 2020 3:7

(1) $\ldots \ldots \ldots \ldots \ldots \ldots \ldots \ldots \ldots \ldots \ldots \ldots \ldots \ldots \ldots . \ldots \ldots$

$(2) \ldots \ldots \ldots \ldots \ldots \ldots \ldots \ldots \ldots \ldots \ldots \ldots \ldots \ldots \ldots 188$

1965 Trade Marks Act S. 19(2) (embodied in Cap. T13 Laws of the Federation 2004 .45

(3) 45
S.21(1)
45
(2).
...45
(3). . .45
(4).
.47
(5).
.47
(6).
47

S. 28 . 203

1965 Trade Marks Act S. 29 (embodied in Cap. T13 Laws of the

S. 38 . 188, 259

(1). 259

(2) 258, 259

(2) (b) 258

(3). .259

(4). .259

(5) .259

S. 47 . I.....40

48 .41
S. 49 . . .41
S. 49-53. ..41
S. 51 . .42
S. 54 . .43
S. 55 . .44
S. 56 . .45
S. 57 .46

1965 Trade Marks Act 6.58 (embodied in Cap. T13 Laws of the

Federation 2004 30
S. 59 . 31
S. 60 . 31
S. 61 . .32
S. 63 .33
S. 64 . .33
S. 67 .34
S. 68(1) Second Schedule. .35

(1) Second Schedule. .36

1994 Trade Marks Act (U.K). 37

1994 Trade Marks Act S. 23(1)-(4) (u.k) 38

\section{SECTION C PATENTS AND DESIGNS ACT PATENTS ACT}


Patents Act. U.K.

Patents and Designs Act S. 1(1) (embodied in Cap P2 Laws of the

Federation

1970 Patents and Design Act S.1 (2)(b) (embodies in Cap. P2 Laws of the Federation, 2004). 29

S.2 (1) 30

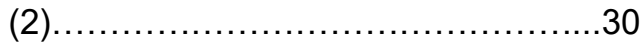

(3) .30

S. 7 (1). 36

(6). 398

(1). 397

1970 Patents and Design Act S.30 (1) (embodied in Cap. P2 Laws of the Federation, 2004). .43

Patents and Design Act Rule 1 First Schedule 44

Patents and Designs Act First Schedule paragraph 3, 4, 5. .45

Paragraph 6,7. . .46

Part 1 Paragraph 13 .46

Part 1 Paragraph 13 . .46

Part 2 Paragraph 15, 16, 17 .46

37. .401

1977 British Statutory Provision Act S.3 47

\section{INDUSTRIAL DESIGN ACT}

1787

Industrial Designs Act

U.K .28

1794 Industrial Designs Act U.K .29

1970 Patents and Design Act S. 21 (2) ( (embodied in Cap. P2 Laws of the Federation, 2004. 45

(d). 45

S.22. .46

(1) (b) .47

(2) (a) (i)-(iii) . .48

(a)-(b) .48

(3) (a)-(b) .48 S.23(1) (a) 49

(b) .50

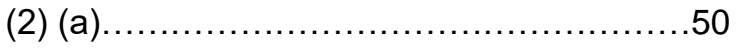

(b) .............................................. 50

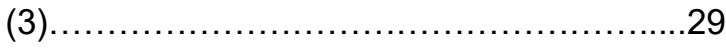

(a)-(c). 
TABLE OF INTERNATIONAL INSTRUMENTS

Berne Convention

Trade Related Aspect of Intellectual Property Rights (T.R.I.P.S)

The Universal Copyright Convention

World Intellectual property Organisation (WIPO)

University Copyright Commission (UCC)

Rome Convention

\section{LIST OF ABBREVIATIONS}

A.C Appeal Case

All ER: All England Report

APP: $\quad$ Appeals

CA: $\quad$ Courts of Appeal

CAP: $\quad$ Chapter

Dist: District

ECSLR: $\quad$ East Central State Law Report

E.R: $\quad$ England Report

FCA: $\quad$ Federal Court of Appeal

Ibid: Same authority and author

LFN: $\quad$ Laws of Federation of Nigeria

LR: $\quad$ Law Report

NMLR: Nigeria Monthly Law Report

Vol: Volume

WLR: $\quad$ Western Law Report

WNLR: Western Nigeria Law Report

UNESCO: United Nation Educational, Scientific and Cultural Organisation 